\title{
The Fatal Attraction of Civil War Economies: Foreign Direct Investment and Political Violence. A Case Study of Colombia. ${ }^{1}$
}

\author{
David Maher \\ Directorate of Politics \& Contemporary History, The University of Salford, UK, M5 4WT. \\ Email:‥j.maher@salford.ac.uk
}

This is an Accepted Manuscript of an article to be published in the journal International Studies Review (published by Wiley) in 2015.

\begin{abstract}
Civil war acutely inhibits economic growth, according to a prominent set of civil war literature. However, recent scholarship observes that Foreign Direct Investment (FDI), considered a central vehicle of growth, is entering countries with internal armed conflicts unabated. Furthermore, some civil war economies exhibit substantial increases in FDI during conflict. According to this scholarship, FDI enters conflict zones in spite of violence. This article contrastingly adopts a critical framework acknowledging the often violent characteristics of globalised capitalism. By analysing Colombia's oil industry (the country's largest sector of FDI), this article suggests that civil war violence can create conditions that facilitate FDI inflows. More specifically, this article posits that violence perpetrated by armed groups sympathetic to the interests of the oil sector - namely, the public armed forces and right-wing paramilitaries - have facilitated FDI in Colombia's oil sector. In particular, processes of forced displacement and violence against civilian groups have served to protect economically important infrastructure and have acquired land for oil exploration. Moreover, civilian groups deemed inimical to oil interests have been violently targeted. By using disaggregate-level data on the conflict in Arauca, an important oil producing region of Colombia, this case study indicates that intensifying levels of civil war violence in areas of economic interest are followed by increases in oil production, exploration and investment.
\end{abstract}

\footnotetext{
${ }^{1}$ I would like to thank Doug Stokes, Ruth Blakeley, Christopher Cramer, Hugh Miall, Claudia Cruz Alvarez and the anonymous reviewers for their feedback and suggestions.
} 


\section{INTRODUCTION}

A prominent set of civil war literature claims that internal armed conflicts severely inhibit economic development. ${ }^{2}$ In this context, this article addresses an emerging yet under researched area of scholarship into civil war and Foreign Direct Investment (FDI). Nascent scholarship which considers FDI to be a central vehicle of economic development - is increasingly revealing that FDI is entering many civil war economies unabated; further, at times, countries with civil wars attract significant increases in FDI.

According to this scholarship, given the large scale destruction that civil wars produce, FDI is entering conflict zones in spite of civil war violence. In contrast, the following analysis adopts a critical framework acknowledging the often violent character of globalized capitalism. In this light, this article investigates if civil war violence can be linked to economic growth and, in particular, if such violence can facilitate inward flows of FDI. To investigate these links, the case of Colombia is discussed, a country that has exhibited strong increases in FDI during the 2000s and, at the same time, continues to experience endemic levels of violence. Analysis focuses on the oil sector, which attracts the largest proportion of FDI in Colombia when compared to other sectors. Further, analysis is concentrated on the department of Arauca, ${ }^{3}$ an oil rich region of Colombia. By using data disaggregated to the department and municipal level, an attempt is made to give insights into the local dynamics of violence and their national level effects.

The central arguments are as follows: working in concert, violence perpetrated by Colombia's public security forces and paramilitaries against both left-wing guerrillas and civilians has: (1) served to protect oil infrastructure from guerrilla attacks; (2) cleared areas of guerrillas and civilians for further oil exploration, and subsequently provided security for economic interests in these areas; and (3) attacked civil groups deemed inimical to the oil sector, including trade

\footnotetext{
${ }^{2}$ Defining civil wars has proven difficult and a consensus remains elusive (e.g., see Sambanis, 2004). Pertinent to the following analysis, Colombia's conflict is consistently coded as a civil war or an internal armed conflict in the datasets commonly used for civil war analysis. (For instance, see the following datasets: Sarkees 2000; Gleditsch et al. 2002; Lacina and Gleditsch 2005; Themnér and Wallensteen 2012a; UCDP 2013.) This article employs a broad definition of civil war violence that includes forced displacement and violence against civilians perpetrated by recognized armed groups of a particular conflict. In Colombia, this refers to the public armed forces, paramilitary groups and guerrilla organizations. Furthermore, the terms "civil war," "intra-state conflict" and "internal armed conflict" are used interchangeably.

${ }^{3}$ Colombia is comprised of 32 departments, which are divided into 1,119 municipalities.
} 
unions and indigenous groups opposed to further oil exploration.

\section{“DEVELOPMENT IN REVERSE,” FDI AND CIVIL WAR}

A prominent set of literature within civil war studies suggests that internal armed conflicts have inherently destructive effects on physical, human and social overhead capital that severely inhibit economic growth (Collier 1999, 2000; Stewart and FitzGerald 2001; Murdoch and Sandler 2002a, 2002b, 2004; Collier et al. 2003; Bodea and Elbadawi 2008; Skaperdas et al. 2009; World Bank 2011; Collier and Duponchel 2013). This literature supports an often cited dictum: that civil war represents "development in reverse" (Collier et al. 2003). The negative economic impacts of civil wars have been described as "astronomical" (Collier et al., 2003: 80) with "dramatic and long-lasting" effects (World Bank 2011:64), and civil wars are said to have "titanic consequences" for economic growth (Collier and Duponchel 2013:66). According to one estimate, a civil war lasting 15 years reduces per capita GDP by 30 percent (Collier 1999:175).

One reason for this detrimental effect is the claim that intra-state conflict inhibits foreign investment (Stewart and FitzGerald 2001; Murdoch and Sandler 2002a, 2002b, 2004; Collier et al., 2003; Blanton and Apodaca 2007). Civil war, it is argued, directly and indirectly destroys assets, increases operating costs to firms, and augments political uncertainty. As MihalacheO'keef and Vashchilko (2010) note, conventional wisdom (in other words, the "development in reverse" logic) strongly suggests countries marred by political violence are wholly incapable of attracting foreign direct investors. For the development orthodoxy, this poses an obstacle to development in the Global South.

Indeed, FDI has become an increasingly important facet of the global political economy, especially in the context of what is often termed "neo-liberal" globalization (e.g., see Williamson 1990). Also referred to as the Washington Consensus, the liberalization of inward FDI aimed to produce unrestricted flows of foreign investment in the global economy. ${ }^{4}$ The global expansion of the neo-liberal economic model has thus augmented the role of FDI in many developing economies. Data show that FDI stock in developing countries has risen dramatically over the past 30 years, from \$297 billion in 1980 to $\$ 6.6$ trillion in 2011

\footnotetext{
${ }^{4}$ Other core policy instruments include trade liberalization, fiscal discipline, liberalizing interest rates, competitive exchange rates, privatization of state enterprises, strengthening property rights and market deregulation (see Williamson 1990).
} 
(UNCTAD n.d.). Further, it is argued that developing countries "clearly rely on FDI as a major source of capital, which is an integral part of economic and political development processes" (Mihalache-O'keef and Vashchilko 2010:137). ${ }^{5}$

\section{Econometric Analyses}

Despite the pervasiveness of the "development in reverse" logic within civil war studies, Murdoch and Sandler (2004:138) lament that "little effort has been expended to isolate the dynamic influences of civil wars on economic growth," as most civil war scholars, with few exceptions, have instead focused on investigating the determinants and duration of civil wars. ${ }^{6}$ Similarly, Driffield, Jones and Crotty (2013:141) point out that the literature analyzing why some firms invest in conflict zones is "extremely limited" and "surprisingly little is also known about the motivations for firms to invest in such volatile locations" (see also Mihalache-O'keef and Vashchilko 2010). And while studies have analyzed the motivations of firms to invest in highly volatile climates, extreme cases such as armed conflict are often overlooked (Driffield, Jones and Crotty 2013:141). For example, in terms of understanding why firms invest in politically risky countries, "virtually all" of the research "addresses the issue in terms of corruption" and "very little has been done on analysing the types of firms who invest in systematically risky environments" (Driffield, Jones and Crotty 2013:141).

Moreover, scholarship analyzing how FDI flows are affected by political risk and instability which may include (and be grouped together as a single risk variable) civil war, terrorism, civil disorder, ethnic violence, and so on - has produced contrasting results and the "econometric evidence is . . . mixed and inconsistent across studies" (Li 2006:226; Li provides a good overview of this literature). For example, Li's (2006) research finds that, on the whole, political violence has no influence on investment location choice, with only a weak negative effect on the amount invested, ${ }^{7}$ while Globerman and Shapiro (2003) find that political instability/violence had no significant effect on whether a country receives US FDI but suggest that the amount of US FDI will be lower in countries experiencing political instability/violence. Other studies (Jakobsen and de Soysa's 2006; Busse and Hefeker 2007; Suliman and Mollick

\footnotetext{
${ }^{5}$ Despite this assertion, the efficacy of FDI to stimulate development is subject to debate (e.g., Sumner 2005; see also footnote 11 below).

${ }^{6}$ Civil war scholars who have addressed FDI and civil war have also tended to focus on how the former affects the likelihood or duration/intensity of the latter (for example, Barbieri and Reuveny 2005; Blanton and Apodaca 2007).

${ }^{7}$ However, Li's (2006) study also suggests that unanticipated civil wars have a negative effect on FDI flows.
} 
2009) indicate that political violence such as civil war is linked to reduced FDI inflows.

Notwithstanding these inconsistencies, more recent scholarship illustrates an increasingly obvious trend: countries with internal armed conflicts are attracting FDI (Mihalache-O'keef and Vashchilko 2010; Driffield, Jones and Crotty 2013). Furthermore, according to MihalacheO'keef and Vashchilko (2010:144-5), flows of FDI during conflict episodes do not significantly differ from inflows during peacetime, with some countries recording substantial increases. One explanation pertains to different types of FDI. For example, it is argued that primary-sector FDI is inclined to enter conflict zones because firms operating in this sector are bound by natural resources or geography (Mihalache-O'keef and Vashchilko 2010; Driffield, Jones and Crotty 2013). Bilateral Investment Treaties are also argued to compensate for policy uncertainty linked to civil war (Mihalache-O'keef and Vashchilko 2010:151).

\section{A Case of Historical Amnesia?}

While the quantitative investigations outlined above have delivered mixed results, these studies nevertheless share a common view: that political violence is incongruent with processes of economic development such as FDI. In other words, even those studies demonstrating that FDI is not deterred by civil wars nevertheless assume that FDI enters conflict zones in spite of civil war violence. Moreover, the econometric studies noted above assume that political instability such as civil war exclusively presents risks to investors.

Christopher Cramer $(2002,2006)$ highlights the problematic nature of such conclusions. For instance, he argues that the "development in reverse" logic is underpinned by a liberal perspective of violence and war that presumes all violent conflict to be exclusively negative in its economic consequences (Cramer 2002:158). Such arguments, according to Cramer, suffer from historical amnesia, as economic development has typically been "accompanied by, hastened by and made by appalling human disruption and violence" (Cramer 2006:9,17). Violence and war have often been and still frequently are "integrated into the appropriation and production process" (Cramer 2006:17; see also Escobar 2004). Similarly, Charles Tilly (1990:196-7) has highlighted the importance of war and war making to the creation and transformation of European states and capitalism, which, despite obvious diversity, can be extrapolated to contemporary debates (see also Taylor and Botea 2008; Blattman and Miguel 2010:4,43; Hough 2011).

Such a critical framework casts doubt on the estimated economic losses related to civil war 
violence. These estimations only consider the economic costs of civil war, overlooking the possibility that civil war violence can also provide economic opportunities and thus, in certain instances, can benefit economic growth. ${ }^{8}$ For example, in the context of FDI, if violence disrupts existing rights to assets (for instance, land or natural resources), then the promotion of conflict or the exclusion of local interests by violent means may present new ownership and investment opportunities to foreign capital (Cramer 2006:233), with a detrimental impact on the welfare of large swathes of people. Therefore, while it is true that capitalism often requires peace and stability, it also "thrives on war and instability and is typically implanted through violence" (Cramer 2006:204).

\section{Large-N Models and Case Study Analyses}

Compounding the theoretical differences outlined above is a disjuncture between case study investigations of individual armed conflicts and large- $\mathrm{N}$, quantitative analyses of civil wars (Cederman and Gleditsch 2009), the latter a method typically employed by the prominent set of civil war literature and econometric studies into civil war and FDI. Colombia is a case in point: critical scholars have argued that violence in Colombia's conflict has often bolstered economic development under a capitalist logic (Escobar 2004; Coleman 2007; Grajales 2011; Thomson 2011; Maher 2014). For example, while some scholars posit that forced displacement inhibits economic growth (Murdoch and Sandler 2002, 2004; Skaperdas 2009), Escobar (2004:214) conversely argues that displacement has opened up entire regions for transnational capital. More specifically, it is argued that displacement can clear lands of inhabitants who reside in areas rich in natural resources, which are subsequently extracted by domestic and transnational corporations. These arguments resonate with Cramer's (2006:217) critique of the "development in reverse" logic, whereby he identifies the dual process of forceful asset accumulation and forced displacement as central to much of the violence and war around the world. ${ }^{9}$

This disjuncture may be a consequence of what Cramer $(2002,2006)$ argues are deep methodological flaws inherent to large-N studies into civil wars, including (but not limited to)

\footnotetext{
${ }^{8}$ These estimations are also problematic to measure (Moser 2000; Blattman and Miguel 2010:38).

${ }^{9}$ Cramer (2006) identifies this process as primitive accumulation (Marx 1990:873-95); however, the application of primitive accumulation to contemporary debates, including its derivatives such as "accumulation by dispossession" (Harvey 2003), can be contested (for instance, see Glassman 2006). Nevertheless, critical scholars largely acknowledge that capitalist accumulation was a violent process in its incipiency and continues to be violent in many parts of the world. It is this broad framework that is applied throughout this article.
} 
overly simplistic proxies to measure complex concepts such as economic development, inequality, greed, grievances, and so on (in the Colombian context, see Gutiérrez Sanín 2004, 2008). Moreover, the reliance on battle-related deaths within the prominent set of civil war literature is problematic. As Kaldor (2013:7) argues, this measure of violence - which is typically limited to fatalities resulting from combat between belligerent groups (e.g., Lacina 2009:3) - overlooks major episodes of civil war violence. This includes forced displacement and violence aimed at civilian groups.

Analyzing the two latter types of violence can provide fuller insights into the dynamics of civil wars and development. For example, forced displacement typically affects a much greater proportion of the population than battle deaths. In Colombia's conflict, battle deaths hit a peak of 3,131 in 2007 (Lacina and Gleditsch 2005); in the same year, 305,966 people were forcibly displaced (CODHES 2011:4). Similarly, focusing on battle deaths largely overlooks the sector of society that is overwhelmingly affected by civil war violence and at whom development strategies are typically aimed: the civilian population. In light of these points, investigating how civilians are affected by civil war violence is crucial for understanding how this type of conflict affects broader political and economic processes.

\section{Disaggregating the Debate}

A further issue with large-N studies is their reliance on aggregate, national level data to analyze civil war. Indeed, there is widespread acknowledgement within civil war studies that internal armed conflicts rarely (if ever) engulf whole nations and are instead limited to particular regions of host countries (Cederman and Gleditsch 2009; Blattman and Miguel 2010). Economic development - including concentrations of FDI - also varies across countries. Aggregate-level approaches are thus increasingly understood to be problematic and emerging scholarship has encouraged the use of disaggregated data to better understand the dynamics of civil wars (for an overview, see Blattman and Miguel 2010; for datasets, see Raleigh et al. 2010; Melander and Sundberg 2011). ${ }^{10}$ In this context, it can be argued that economic growth can be fostered in civil war economies if the fighting takes place away from economically important regions within countries (Skaperdas 2009:2). Similarly, the risks to foreign direct investors can be low

\footnotetext{
${ }^{10}$ Similar to broader trends in civil war scholarship, most disaggregated studies into civil war and development have focused on civil war onset (e.g., Buhaug and Rød 2006; Hegre, Østby and Raleigh 2009). One exception is Collier and Duponchel's (2013) study, which suggests negative economic impacts of civil war violence in Sierra Leone. The authors, however, acknowledge limitations of the firm level data they use. Other studies have analyzed the negative effects of civil wars on individual human capital (see Blattman and Miguel 2010:41-42).
} 
if conflict occurs away from areas of economic interest (Mihalache-O'keef and Vashchilko 2010:148).

The following analysis focuses on areas of economic interest in Colombia, namely, oil producing regions. Colombian government statistics on forced displacement are used, which have been compiled and collated by this author at the department and municipal level. Data on political violence and human rights violations, published by a Colombian human rights group, Centro de Investigación y Educación Popular (CINEP), are also employed and have been further coded by this author to provide a uniquely coded dataset disaggregated to the department and municipal level (see Appendix A). In this way, the following analysis applies the emerging technique of disaggregating conflict data to empirically contribute to anecdotal and qualitative evidence on the links between violence and economic development in Colombia. Before discussing the regional dynamics of Colombia's violence and development, however, it is first necessary to outline the country's broader economic and violent trends.

\section{ECONOMIC DEVELOPMENT AND CIVIL WAR IN COLOMBIA}

Colombia is a middle-income country that has traditionally exhibited stable economic growth (Holmes, Gutiérrez and Curtin 2008:28; World Bank 2011:113). Nevertheless, the following analysis focuses on the country's economy from 1990 onwards, when the government began fervently adopting neo-liberal market liberalization policies. Beginning with a process known as la apertura económica (the economic opening), the Colombian government has rapidly opened up the economy to foreign investors. Indeed, privatization in Colombia is "open without any limitations to foreign investors," according to the OECD (2012:9), and the private sector now constitutes $85 \%$ of the country's GDP.

As Figure 1 shows, Colombia exhibited strong economic growth during the 2000s, when GDP per capita $^{11}$ grew at an average rate of $2.5 \%$, compared to $1 \%$ in the 1990 s. (World Bank n.d.). The economy exhibited a particularly strong period of growth between 2004 and 2007, when per capita GDP growth averaged 4.3\%. Slower growth rates were exhibited during 2008 and 2009 as the Colombian economy felt the effects of the global economic crisis (OECD 2012:18), but recovered strongly in 2010 and 2011, exhibiting GDP per capita growth rates of $2.6 \%$ and $4.5 \%$, respectively. $^{12}$

\footnotetext{
${ }^{11}$ At constant 2000 US\$.

${ }^{12}$ Despite economic growth, levels of poverty and inequality remain acute. For instance, when neo-liberal
} 
Colombia's impressive economic growth during the 2000s has been buttressed by a remarkable influx of FDI, with FDI stock increasing from $\$ 11.2$ billion in 2000 to $\$ 95.7$ billion in 2011, increasing at an annual average of $22 \%$. As with GDP, FDI growth has been particularly strong between 2004 and 2007 (Figure 1). FDI has accounted for 27\% of Colombia's GDP in recent years and, at times, annual FDI inflows have ranged from between 19\% (during 2006-2008) to $36 \%$ (in 2005) of Colombia's gross fixed capital formation (see OECD 2012:19-20).

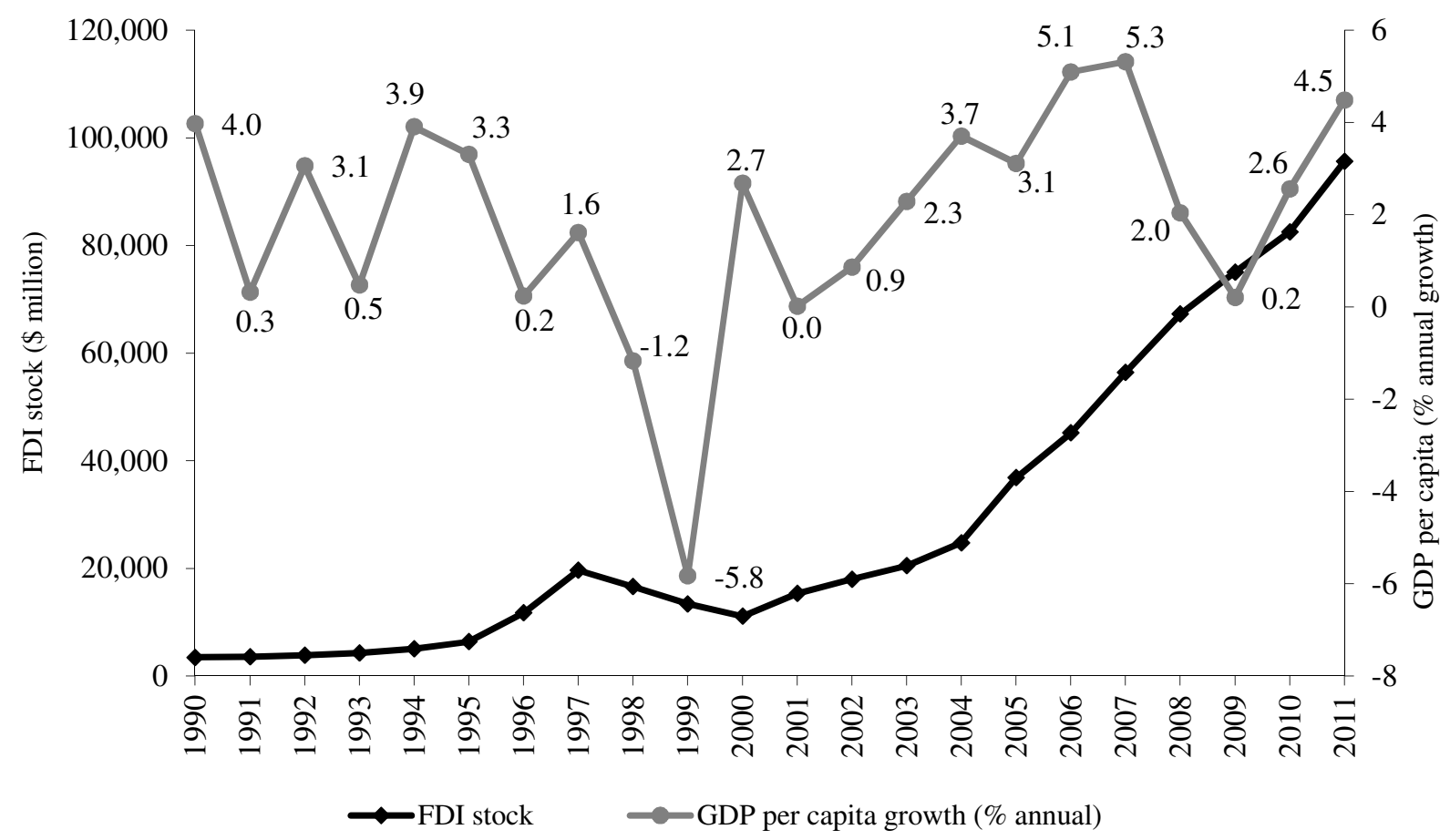

FIG 1. FDI Stock and GDP Per Capita \% Annual Growth Rates in Colombia, 1990-2011

Source: World Bank (n.d.) and UNCTAD (n.d.)

\section{FDI and Oil}

The petroleum industry attracted most FDI in Colombia in 2012 when compared to other sectors, totaling $\$ 5.4$ billion (34\% of the total), followed by $\$ 2.3$ billion (15\%) in the mine and quarry sector (Banco de la República n.d.). Since 1999, the Government of Colombia (GOC) has introduced measures to create a more attractive investment climate for foreign oil companies as part of its implementation of neo-liberal economic policies. This includes, inter

restructuring began in 1991, the richest $10 \%$ of Colombia's population held a $39.5 \%$ share of the country's total income, rising to $44.4 \%$ by 2010 (although the figure has undulated; see World Bank 2012). 
alia, permitting foreign oil companies to own $100 \%$ stakes in oil ventures; a lower, sliding scale royalty rate on oil projects; longer exploration licenses; and the partial privatization of Ecopetrol (the incumbent state oil company), which is now forced to compete with private investors (US Energy Information Administration 2011; US Department of State 2011).

Annual inflows of FDI to Colombia's oil sector have strongly increased from \$521 million in 2001 to $\$ 1.2$ billion in 2005, \$3.4 billion in 2008 and $\$ 5.4$ billion in 2012 (Banco de la Republica n.d.). Oil production has increased from an average of 525,000 barrels of crude oil per day (bpd) in 2005 to 944,000 bpd in 2012 (García Carrizosa 2008; Unidad de Planeación Minero Energética n.d.). With strong increases in oil production, new infrastructure projects are emerging across Colombia to bolster the country's capacity to transport oil to market (Kraul, 2011). This includes numerous pipeline projects that, at a cost of around $\$ 7$ billion, aim to double Colombia's oil producing capacity to 1.4 million barrels a day (Kraul 2011).

Oil production and new infrastructure projects have been stimulated by favorable investment conditions and, crucially, improved security for oil investors. This includes confidence in the GOC's ability to protect oil infrastructure, which had previously represented an acute problem for investors, with Colombia's left-wing guerrilla groups often targeting oil infrastructure (DOS 2001a:7-8; DOS 2002c:2; Stratfor 2002; GAO 2005:18-19).

\section{The Civil War}

Colombia's civil war has existed since at least the early 1960s and involves the public armed forces, right-wing paramilitaries and left-wing guerrillas. During the 2000s, the dynamics of Colombia's civil war were impacted by a US aid package to Colombia. Typically referred to as Plan Colombia, this package totaled $\$ 8.5$ billion between 2000 and 2012, with the majority (74\%) allocated to Colombia's military and police (see Just the Facts 2012; author calculations).

Despite claims to the contrary (World Bank 2011), Colombia's civil war violence has intensified during the 2000s and throughout the period of economic growth highlighted above. Battle-related deaths averaged 1,173 between 1990 and 1999 compared to 2,452 between 2000 and 2008 (Lacina and Gleditsch 2005; data post-2008 were not available). Colombia's largest left-wing guerrilla group, the Revolutionary Armed Forces of Colombia (commonly known by its Spanish acronym, FARC), conducted an average of 1,035 military actions in the period 1997-2000 but conducted an average of 1,493 actions in the 2007-2010 period (Ávila Martínez 
2011; author calculations). ${ }^{13}$ With the exception of 2008, the annual numbers of Colombian soldiers and police officers killed were higher between 2003 and 2010 than in 2002 (Ávila Martínez 2010:22), the latter typically considered the height of Colombia's armed conflict (Leech 2011:139). According to CODHES (2011:3-4), a Colombian human rights group, 5.3 million people were forcibly displaced as a result of the conflict between January 1985 and June 2011, of which 65\% were displaced between 2000 and 2011 (author calculations). ${ }^{14}$

In this light, security for oil investors has improved as the civil war intensified. This is evidenced by the fall in infrastructure attacks during the 2000s: in 2009, there were 76 attacks on pipelines, roadways and bridges in Colombia, a sharp decline from 800 attacks recorded in 2002 (Bloomberg 2011). Nevertheless, as discussed above, while the civil war violence has risen on a national level in Colombia, a disaggregate-level approach focusing on key oil producing regions will provide clearer insights into the links between civil war violence and FDI in the oil sector.

\section{THE DEPARTMENT OF ARAUCA}

Writing in 2011, Kraul (2011) explains that while "the eastern jungle plains region of Llanos" were until recently "firmly in the grips of leftist guerrillas," this area is "now the scene of most of Colombia's oil growth" following improved security for oil investors. One such area is the department of Arauca, located in the Llanos region of north-eastern Colombia. Largely a savannah terrain, Arauca consists of seven municipalities: Arauca (the departmental capital; henceforth: Arauca Municipality), Arauquita and Saravena, all in the north of the department; and Cravo Norte, Fortul, Puerto Rondón and Tame, located in the south of Arauca. In 1983, US oil company Occidental Petroleum (OXY) discovered one of Colombia's largest oilfields in the department, known as Caño Limón, turning Arauca into one of Colombia's most important oil producing regions. Arauca's oil, which is pumped from Caño Limón to the town of Coveñas on Colombia's Caribbean coast (north-west Colombia) via the 477-mile Caño Limón-Coveñas pipeline, has generated strong revenues for the Colombian government and oil corporations (DOS 2002a:5-7; GAO 2005:5).

\footnotetext{
13 The Colombian government and the FARC began formal peace talks in October 2012. At the time of writing, this process has not concluded and is not discussed.

${ }^{14}$ Internal displacement figures used throughout this article are cumulative and do not show the number of internally displaced persons (IDPs) who have relocated and resettled.
} 
Arauca has been a traditional stronghold of the guerrillas, especially the National Liberation Army (known by its Spanish acronym, ELN), although the FARC expanded its presence in the region throughout the 1990s (León 2003). By 2003, there were an estimated 1,000 ELN combatants in the department and approximately 2,000 FARC soldiers (León 2003). Despite the presence of armed groups in the department (including paramilitaries, discussed below), traditionally there has been a modest amount of coca cultivated in Arauca; indeed, even at its peaks, cultivation has been low when compared to other regions of Colombia (UNODC 2009). Instead, the guerrillas' attention has typically been directed at the oil industry.

Bolstered by the threat of attacking oil infrastructure and employees, a central aim of the guerrillas has been to extort money from oil companies and their contractors. Payments to the rebels have been extensive; for instance, during the initial years of the Caño Limón operation, OXY and its subcontractors paid the guerrillas between $\$ 1$ million and $\$ 5$ million to prevent pipeline attacks (see Witness for Peace 2002:8). In 2003, Colombian authorities further calculated that the ELN, which has traditionally infiltrated Arauca's political landscape, had profited from between $\$ 200$ million to $\$ 1.2$ billion from royalties paid by oil companies since 1986 (León 2003; see also Witness for Peace 2002:8; Sierra 2003).

Despite these payments, the Caño Limón-Coveñas pipeline has been repeatedly attacked by the guerrillas, causing serious disruption to production and significant financial losses for OXY and the Colombian state (Presidencia de la República 2003:25; GAO 2005:1; Leech 2006:152). Between 1985 (when oil operations began) and 2003, the pipeline was attacked 915 times (Sierra, 2003). Statistics provided by OXY show that attacks on the pipeline intensified during the 1990s and early 2000s, reaching a peak of 170 attacks in 2001. During this peak, attacks by rebel groups reduced production by an estimated 70,000 barrels of oil per day and rendered the pipeline out of service for total of 240 days (GAO 2005:1; Leech 2006: 152). The GOC estimated that it lost $\$ 520$ million in revenue in 2001 due to these attacks (Gobierno de Colombia 2003:25) and the resultant halts to production cost OXY \$100 million in lost earnings (Leech 2006:152).

\section{The Public Armed Forces and US Aid}

In light of this guerrilla activity, the GOC focused on expanding and consolidating its military presence in Arauca to protect the pipeline from guerrilla attacks. In September 2002, the then newly elected hardline president, Álvaro Uribe (in office 2002-2010), created a so-called 
"Rehabilitation and Consolidation Zone" (RCZ) in the department, which expanded across Arauca Municipality, Arauquita and Saravena. On the one hand, the guerrillas commanded a strong presence in these municipalities. On the other hand, these areas are strategically crucial for protecting oil interests in the area because the Caño Limón oil complex is located there (Arauca Municipality/Arauquita) and the oil pipeline traverses these municipalities (Isacson 2003:16; Amnesty International 2002, 2004).

As Figure 2 shows, bombings of the Caño Limón-Coveñas pipeline declined sharply after 2001. This coincides with a controversial US military aid package, known as the Caño Limón initiative, passed through US Congress in response to increases in pipeline bombings in Arauca. As part of the 2002 counter-terrorism bill, US Congress granted an extra $\$ 99$ million in military aid as an adjunct to Plan Colombia for the protection of the Caño Limón pipeline (GAO 2005). While the guerrillas' predilection for bombing the pipeline continued well after the Caño Limón initiative was implemented (as Figure 2 shows, the guerrillas continue to target the pipeline; see also Dudley 2002), pipeline attacks declined from a peak of 170 in 2001 to 41 in 2002. By July 2005, pipeline attacks had fallen to 13 .

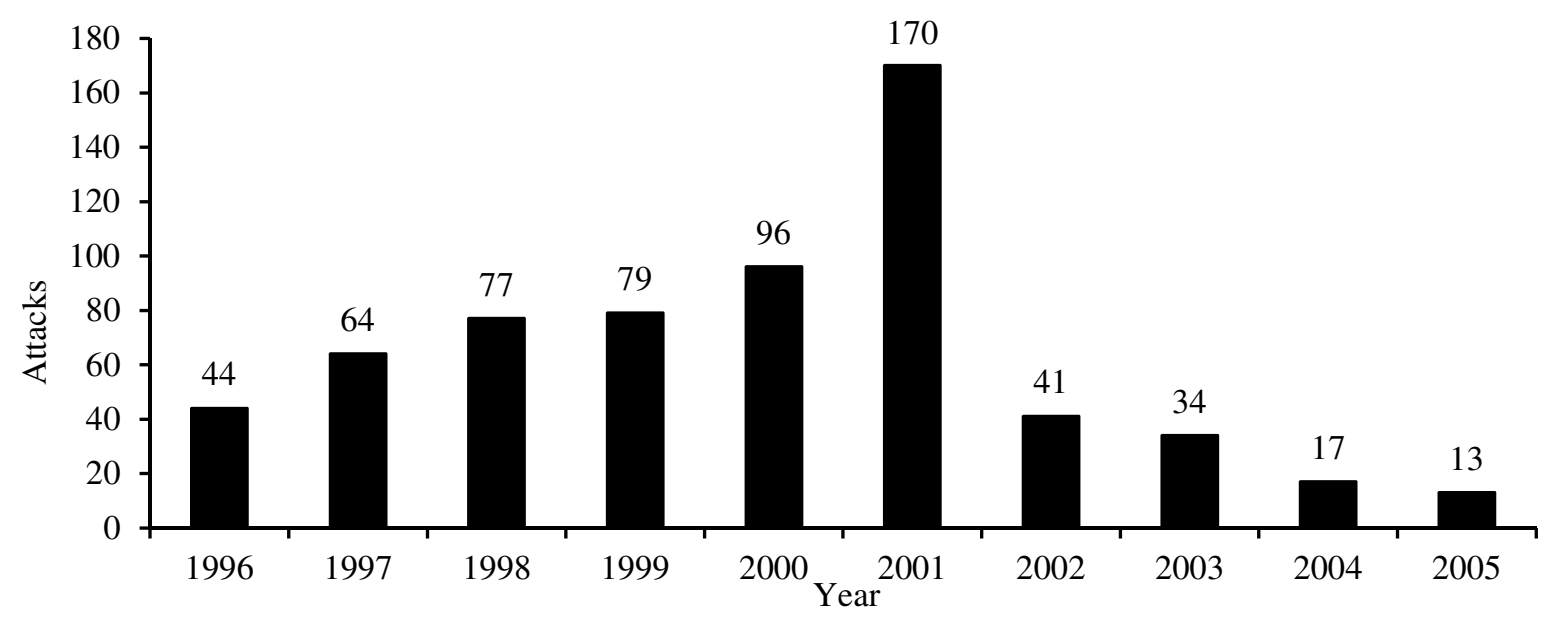

FIG 2. Attacks on the Caño Limón-Coveñas Pipeline (1996 - July 2005)

Source: GAO 2005, 15, figure 4

Closer inspection reveals that the bulk of this aid had a very limited (if any) effect on establishing pipeline security. The majority ( $\$ 86.4$ million, $88 \%$ of the total) of the aid was allocated for the purchase of ten helicopters and military equipment, which did not reach Arauca until mid-2005 (see GAO 2005:3-14), well after pipeline attacks had fallen from their peak in 2001. 
Although pipeline bombings were already declining by 2003, $\$ 12.7$ million (13\% of the total) of the initiative appears to have contributed to pipeline security. This portion was allocated for the counter-insurgency training of Colombia's army in Arauca by US Special Forces, which began in January 2003. However, as will be discussed, this portion of the aid also had grave consequences for the civilian population. On the one hand, the US counterinsurgency doctrine is underpinned by human rights abuses against civil society; on the other hand (and relatedly), the doctrine is explicit in advocating close relationships between state security forces and the pervasive use of paramilitaries (Stokes 2005; Stokes and Raphael 2010:71). It is important to note that in Colombia, the paramilitaries have employed widespread violence and are responsible for the majority of human rights abuses (Human Rights Watch 2001; Livingstone 2003; Murillo 2004; Stokes 2005; Hylton 2006; Brittain 2010).

\section{The Paramilitaries in Arauca}

Evidence of military-paramilitary collusion in Arauca is compelling and has been well documented by organizations such as the Office of the United Nations High Commissioner for Human Rights (OHCHR 2003), Amnesty International (2002, 2004), the Washington Office on Latin America (WOLA 2003), Witness for Peace (2002), and CINEP (2011) (see also Verdad Abierta 2009a; Palmer 2010). This is consistent with broader trends in Colombia, where deep links between the armed forces and the paramilitaries have also been well documented (OHCHR 2003; Amnesty International 2002, 2004; Stokes 2005; Hristov 2009; Human Rights Watch 2001, 2005, 2010).

Advancing to Arauca en masse in August 2001, the paramilitaries' expansion into the department preceded that of the public armed forces, a common trend in Colombia's conflict (Leech 2003:23; WOLA 2003:3; Verdad Abierta 2010; Maher 2014). Although operating across Arauca, the AUC established its strongest presence in Tame (Dudley 2002; Sierra 2003), as well as Cravo Norte, Fortul and Puerto Rondón (Sierra 2003; WOLA 2003:3; Amnesty International 2004:33). Importantly, these areas fall outside of the RCZ security perimeter. By 2003, there were 800 to 1,000 paramilitaries operating in Arauca (León 2003). Although the United Self-Defense Forces of Colombia (the paramilitary umbrella group better known by its Spanish acronym, AUC) reached an agreement with the GOC to demobilize between 20032006, the deeply flawed demobilization process enabled powerful successor paramilitary groups to emerge throughout Colombia. Links between these groups and Colombia's armed forces soon emerged (Colombian NGO Platform 2008; Semana 2008; CODHES 2009; Human Rights Watch 2010; Maher and Thomson 2011). In Arauca, during the 2000s, new paramilitary 
groups included the Colombian Revolutionary Popular Antiterrorist Army (known by its Spanish acronym, ERPAC) and the notorious Black Eagles (Aguilas Negras) (Human Rights Watch 2010; Ohlsen Pettersson 2012).

\section{Public Armed Forces-Paramilitary Control}

Protection of the Caño Limón Coveñas pipeline and other vital oil infrastructure has been realized by achieving public armed forces-paramilitary territorial control in areas of economic importance in Arauca, which has thwarted and deterred attacks on oil infrastructure. In terms of the public armed forces, this included military patrols across the networks of roads around the Caño Limón oil fields and proximate jungle areas, the stationing of light tanks, heavily fortified bunkers and rapid-response forces across strategic positions along the pipeline, and the creation of intelligence centers that have served (inter alia) as a basis for the public armed forces' offensive combat operations (DOS 2002b:8, 2003a:7, 2006; Dudley 2002; Forero 2002:1; GAO 2005).

Espousing a "fiercely anti-communist" ideology (Leech 2006:126) and aspiring to "defend the interests of powerful domestic and international economic actors" in Arauca (Amnesty International 2004:5), Colombia's right-wing paramilitary groups also have a central role in bolstering pipeline security. In the department of Casanare (immediately south of Arauca), Richani observes (2002:166) how the paramilitaries have played a direct role in protecting oil pipelines by establishing and consolidating "buffer zones" to diminish the influence of the guerrillas in the areas surrounding pipelines. This strategy pushed the guerrillas from villages located in proximity to oil pipelines and denied the rebels extraction and protection rents realized from oil companies operating in the area (Richani 2002:116). A similar pattern can be observed in Arauca. This includes numerous road blocks and checkpoints operated by the paramilitaries, which have bolstered protection for the Caño Limón complex and the pipeline (Amnesty International 2004:11, 34). Additionally, the paramilitaries deeply penetrated Arauca's political landscape (Semana 2011a; Verdad Abierta 2009a, 2009b), a common trend throughout Colombia where the paramilitaries have generated "enormous political power, at many levels" (Human Rights Watch 2005:16). In Arauca, this helped to weaken revenues that the guerrillas realized from oil royalties, which the rebels achieved by extorting Arauca's politicians and by forcing public works contractors to pay the guerrillas a percentage of public contracts (WOLA 2003; Amnesty International 2004). ${ }^{15}$

\footnotetext{
${ }^{15}$ In 2003, former president Uribe also ordered that royalty payments in Arauca be administered directly from
} 
The expansion of the public armed forces-paramilitary presence to create these buffer zones came at huge costs to the civilian population. For instance, Amnesty International $(2002,2004)$ and other observers (Leech 2002; Isacson 2003) highlight that the RCZ led to a rapid increase in human rights violations, including arbitrary arrests, mass detentions, raids and searches of civilians carried out by the public armed forces. Many of these actions continued unabated after the RCZ was ruled as unconstitutional by Colombia's Constitutional Court (Amnesty International 2004:42-3) in November $2002^{16}$ and Amnesty International (2004:14) continued to document cases of torture, murder and "disappearances" perpetrated directly by the military or in collusion with paramilitaries. Moreover, with support from Colombia's armed forces, the paramilitaries aimed to "purify" Arauca of people deemed to be in support of the guerrillas, vowing to "cleanse the region of guerrillas and their supporters" (Marx 2002:2; WOLA 2003:3). The paramilitaries duly "imposed a regime of terror" in the department (Verdad Abierta 2010) and "sought to keep civilians under control by instilling fear, through massacres, 'disappearances,' and torture” (Amnesty International 2004:43).

\section{Forced Displacement}

This paper posits that forced displacement - which, as noted above, is a widespread problem in Colombia - has been central to the creation of these security buffer zones. That is to say, forcibly displacing civilians acts as "a low cost and effective strategy for clearing out territories" (Ibáñez and Vélez 2008:661), which facilitates the creation of these zones. For instance, large-scale forced displacement of the civilian population weakens the fighting capacity of a rival armed group as it is less able to hide and find support (Azam and Hoeffler 2002). Clearing out civilians from an area allows armed groups to strengthen their regional control and more easily transport supplies including weaponry (Ibáñez and Vélez 2008:661). Furthermore, according to Muggah (2000:204), “individuated security zones" are created in Colombia following forced displacement, as land assets of economic or military strategic value are repopulated with supporters of the attacking armed groups. Forced displacement, therefore, should not be simplistically viewed as a vicissitude of combat but is instead employed as a concerted strategy of war (Muggah 2000; Ibañez and Moya 2010; Ibáñez and Vélez 2008).

At this juncture, it is important to note that the majority of forced displacement in Colombia is

Bogotá (WOLA 2003; Amnesty International 2004).

${ }^{16}$ In April 2003, Colombia's Constitutional Court ruled against renewing the relevant Decree used to establish the RCZ. 
perpetrated by the paramilitaries (see Ibáñez and Vélez 2008:662; Comisión de Seguimiento 2009; Hristov 2009). Moreover, while some scholars (for instance, Ibáñez and Vélez 2008; Ibáñez and Moya 2010) largely overlook the role of Colombia's public armed forces, others observe that the state's forces are responsible for a significant portion of forced displacement (Muggah 2000:204; Brittain 2010:40; Leech 2009, 2011:131; in the Arauca case, see below). Between 1980 and 2010, it is estimated that 6.7 million hectares of the countryside have been abandoned or seized in Colombia due to the armed conflict, representing 13\% of Colombia's total arable land. This excludes the territories of ethnic communities (discussed in more detail below), which would augment this figure (see Comisión de Seguimiento 2010:4).

In addition to spreading territorial control, forced displacement also allows armed actors to diversify sources of funding (Muggah 2000:204; Ibáñez and Moya 2010). For instance, the paramilitaries began controlling the drug trade in Arauca after they established a presence in the department (Amnesty International 2004). ${ }^{17}$ Furthermore, in Arauca (and other oil producing regions of Colombia), the paramilitaries have allegedly received financial contributions from oil corporations, have taxed oil corporations to protect infrastructure and have offered other business services to oil companies (WOLA 2003; Palmar 2010).

\section{Expropriating Land for Oil Exploration in Arauca}

Forced displacement also serves strategic economic aims, especially by expropriating land that is rich in natural resources (Lozano-Gracia et al. 2010). At this juncture, it is important to understand the usual pattern of displacement in Arauca (and Colombia more broadly): people (in particular, peasant farmers and indigenous people) are typically displaced from rural areas and subsequently take refuge in larger towns and cities. Therefore, this movement of people clears economically important rural land of large numbers of inhabitants (Verney 2007, 2008; Lari and Kurtzer 2008; Hristov 2009). This land is subsequently taken over by landed elites, mining companies, agri-business and foreign corporations for commercial operations (Hristov 2009:76; see also Muggah 2000; IDMC 2009; Leech 2009). Employees in the extractive industries (for example, oil workers) are then transported into these areas, which can cause further disruption for people who have not been displaced or people who continue to inhabit the surrounding areas (such as social conflict between oil workers and indigenous groups) (Verney 2007, 2008; Lari and Kurtzer 2008; Hristov 2009; Amazon Watch 2011; IDMC 2012).

\footnotetext{
${ }^{17}$ Increases in coca cultivation in Arauca are recorded from 2001 onwards, when the paramilitaries began entering the department (see UNODC 2005, 15, table 4; 2009, 13, table 3).
} 
In Arauca, Amnesty International (2004:43) notes how the counterinsurgency strategy employed by Colombia's armed forces is designed (inter alia) "to force civilians from land of importance to the oil industry and other economic interests." Lari and Kurtzer (2008) argue that armed groups have escalated the conflict in Arauca to control regions of future oil exploration. Furthermore, Amnesty International (2004:11) and others (Amazon Watch 2002, 2011; Leech 2000a,b; CPDH-Arauca 2012) observe that in Arauca and surrounding areas, peasant farmers and indigenous communities who live close to oil installations and infrastructure, or who occupy land in areas due to be exploited for oil, have faced violence and forced displacement. Specific allegations have also been trained at oil corporations. It is alleged, for example, that OXY is displacing settled communities from their lands in Arauca to advance its oil operations at Caño Limón and claim an additional 5,885 hectares of land in addition to the 2,500 hectares it has already been assigned (see CPDH-Arauca 2012).

While many peasant farmers are undoubtedly affected by forced displacement, a disproportionate number of Afro-Colombian and indigenous people are displaced in Colombia (Escobar 2004; Hylton 2006:6; Hristov 2009). This is because Colombia's ethnic minorities often inhabit territories that are rich in natural resources (Escobar 2004:215-16; Hylton 2006:6; Hristov 2009). Many ethnic groups also fervently oppose oil exploration in Colombia, which will now be discussed.

\section{Silencing Opposition to Oil Interests: Indigenous Groups and Trade Unions}

In addition to acquiring land for resource extraction, forced displacement is aimed at "impeding collective action, damaging social networks, and intimidating and controlling [the] civilian population" (Ibáñez and Vélez 2008:661-62). In this light, forced displacement, as well as broader human rights abuses, has served to silence opposition to the oil industry in Arauca and attack civil groups deemed inimical to the profitability and attractiveness of the sector. As Amnesty International (2004:43) observes, the counterinsurgency strategy employed in Arauca was "designed not only to combat the guerrilla but to silence those campaigning for socioeconomic rights, including those sectors 'obstructing' further oil exploration."

Perhaps unsurprisingly, given that they often inhabit land rich with natural resources, indigenous groups constitute a particular vociferous opponent to the oil industry in Colombia and have faced widespread violence (Rights and Democracy 2001; DOS 2004; Murillo 2004; Permanent Tribunal of Peoples 2007; Hristov 2009; Amazon Watch 2011; Hill 2014). In 
Arauca, indigenous communities have opposed the disruption caused by the oil industry, including the influx of heavy machinery, equipment, and oil workers into their ancestral lands, as well as the environmental damage and disruption caused by the construction of infrastructure needed for oil exploration (for instance, buildings, crude transport systems, oil wells, pipelines, refineries, roads, water treatment facilities, stabilization lakes, military camps, airports, and heliports) (Rights and Democracy 2001:18; DOS 2004; Permanent Tribunal of Peoples 2007; Hristov 2009:187; Amazon Watch 2011; Hill 2014). This opposition by indigenous groups is particularly problematic for oil corporations and the GOC's desire to attract oil investors to the country: enshrined in the 1991 constitution, Colombia's indigenous communities have perpetual rights to their ancestral lands (e.g., DOS 2004).

In addition to indigenous groups, Amnesty International (2004:21; see also WOLA 2003; OHCHR 2003; Palmer 2010) notes that there has been a "coordinated state-paramilitary strategy" in Arauca aimed at stigmatizing civil society, especially Arauca's "long-standing and well-developed human rights and trade union movement." It is thus important to note that, as the Escuela Nacional Sindical (National Trade Union School, ENS) observes, attacks against civil groups such as trade unions in Colombia take place "in the context of war and are committed, in most cases, by one of the belligerent parties" (ENS quoted in ITUC 2007).

Given their often left-leaning political positions, trade unionists (as well as civil society more generally) in Colombia are commonly stigmatized as being members or sympathizers of the left-wing guerrillas (e.g., Human Rights Watch 2010). Moreover, by challenging the privatization of Colombia's natural resources to transnational corporations, Colombia's trade unions oppose central reforms introduced by former president Uribe to revamp the oil industry (DOS 2001b; Michaud 2007). Colombia's national oil union (known by its Spanish Acronym, USO) is a particularly vociferous opponent of such economic reforms and, as with other trade union groups, has been violently targeted with almost total impunity (Stokes 2002, 2005; WOLA 2003; Hristov 2009; Human Rights Watch 2010; Maher and Thomson 2011). Murders, arrests, repression of USO demonstrations and threats against USO workers continue, largely perpetrated by the public forces and paramilitary groups (for example, Justice for Colombia 2013a,b).

This is congruent with broader trends in Colombia, whereby paramilitary groups are responsible for the majority of violence against trade unionists, followed by the public armed forces (Stokes 2005; Hristov 2009; Human Rights Watch 2010). For instance, in mid-2012, 
from 143 reported cases of violence against trade unionists where the responsible group could be identified, $73 \%$ of cases were attributed to the paramilitaries and $24 \%$ to Colombia's public forces. The guerrillas were responsible for approximately $2 \%$ of violations (see ITUC 2012).

In addition to silencing opposition to the privatization of the oil industry, it has been argued that this violent strategy of attacking civil groups such as trade unions has improved the investment climate for oil interests in the area (Stokes and Raphael 2010:72), as wages are kept low and working conditions remain poor (Maher and Thomson 2010). Forced displacement also drives down labor costs by increasing the supply of manual labor and, given their precarious situation, produces a pool of workers desperate for work (Hristov 2009:206-7).

\section{THE CONFLICT IN ARAUCA: DATA}

This section provides a deeper analysis of the violence discussed above by using disaggregated data on civil war violence in Arauca. If critical scholars are accurate and violence can facilitate processes of economic growth such as FDI by protecting economically important infrastructure and acquiring land for commercial activities, in the Arauca case we should expect to see: (1) intensifying levels of violence in areas of economic interest to the oil sector, followed by increases in oil production, exploration and investment. More specifically, we should expect to see: (2) intensifying levels of violence in the municipalities where the Caño Limón oil facility is located and where the pipeline traverses, followed by greater oil production and exploration at Caño Limón; (3) intensifying violence in other strategically important municipalities to the oil sector, followed by further production, exploration and/or investment; and (4) high levels of violence perpetrated by actors sympathetic to the economic interests of the oil sector in the area (namely, the public armed forces and right-wing paramilitary groups). Further, given that the territories of indigenous communities are located close to oilfields in Arauca (Permanent Tribunal of Peoples 2007) and because these communities vociferously oppose the oil sector in the region, the data should show: (5) high levels of violence perpetrated against indigenous groups in municipalities of strategic importance to the oil sector, followed by increased oil production, exploration and/or investment in infrastructure in these areas.

According to data from CINEP (Figure 3), there were 3,223 victims of human rights violations and political violence (henceforth: HRPV) in Arauca during the period 2001-2010. As Figure 3 also shows, from 2001 to 2003 - when the RCZ was established and when military and paramilitaries began to consolidate their presence in the region - violence in Arauca soared. Moreover, when US Special Forces training began in (January) 2003, the number of HRPV 
victims peaked, with 1,337 HRPV victims recorded. After 2003, the number of HRPV victims declined; however, the data show that violations were similar (albeit, at times lower) to 2001 figures, when violence had already risen as the military and paramilitaries began establishing a presence in the region (CINEP data preceding 2001 were not available).

As expected, Figure 3 shows a high number of HRPV victims were recorded in the oil rich municipalities through which the Caño Limón-Coveñas pipeline traverses and where the public armed forces consolidated their presence, namely, Arauca Municipality, Arauquita and Saravena. There were 1,529 victims in these municipalities, representing $47 \%$ of total HRPV victims in Arauca. Moreover, the most affected municipality was the paramilitary stronghold of Tame, where 1,509 HRPV victims (47\% of the total) were recorded. Once aggregated, these four municipalities accounted for $94 \%$ of all HRPV victims in Arauca.

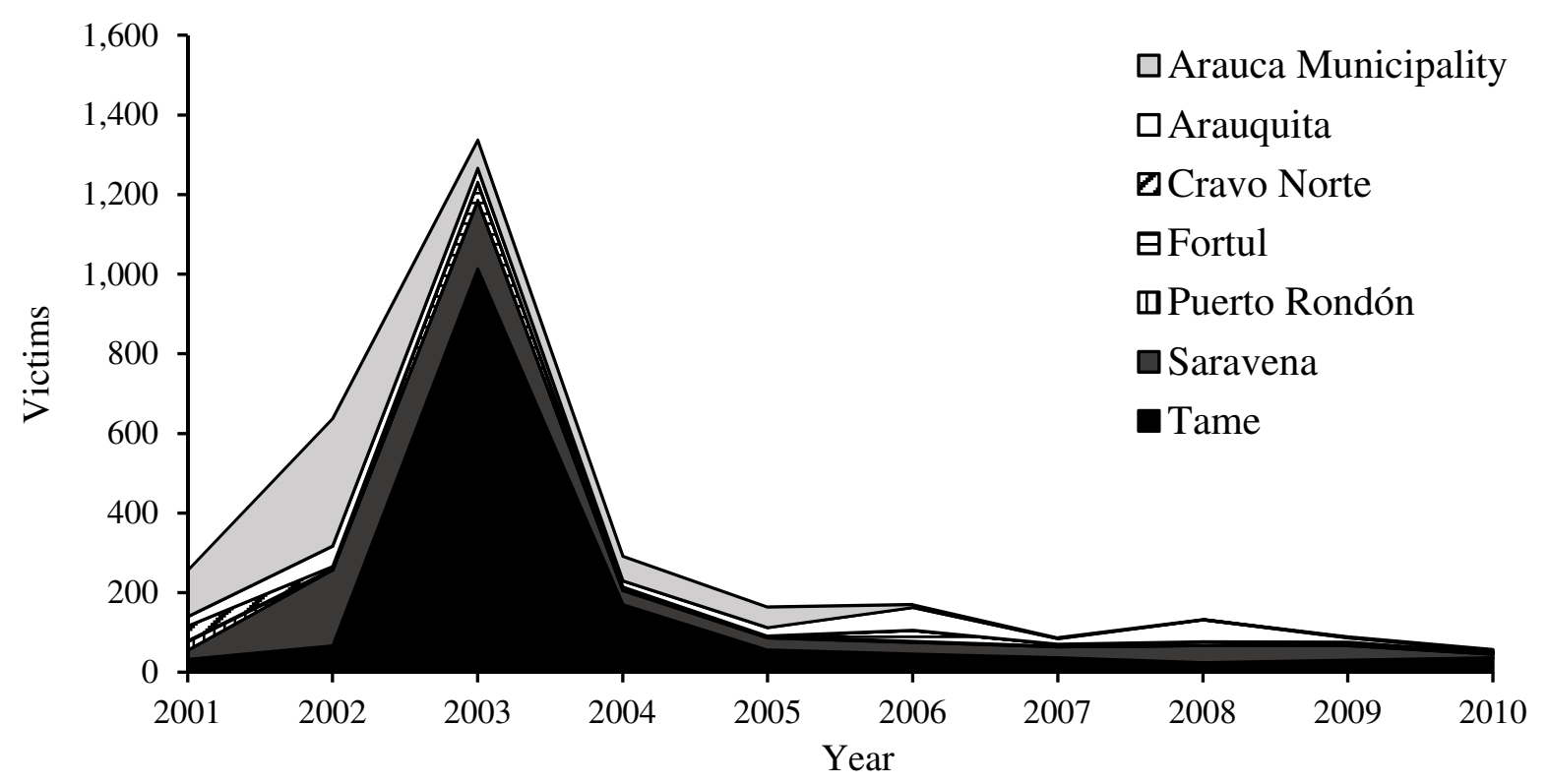

FIG 3. HRPV Victims in Arauca by Municipality, 2001-2010

Source: Data adapted from Banco de Datos de Derechos Humanos y Violencia Política del CINEP (2011)

Throughout 2001 to 2010, Colombia's public forces were responsible for the majority of HRPV victims in Arauca, namely, $47 \%$ of total victims (Table 1). The paramilitaries were responsible for $15 \%$ of HRPV victims. In total, public forces, paramilitary, and combined public forcesparamilitary violence was responsible for $67 \%$ of all HRPV victims (see Appendix B for a discussion of the false positives scandal in Arauca). 
The FARC and the ELN were responsible for $18 \%$ of HRPV victims, highlighting that the rebels intensified their military campaigns to contest public forces-paramilitary consolidation in Arauca. As Leech (2003) argues, the guerrillas have acted with "a brutality that blatantly violates aspects of international law calling for the protection of unarmed civilians" (for similar trends in the department of Caquetá, see Hough 2011; for combat between the FARC and the ELN, see Appendix C). According to one diplomatic cable from the US Department of State, the "rhythm of violence is perceived to have increased" in Arauca and the guerrillas "have fought back hard" (DOS 2003b:2, 6). Combat between the armed forces and the guerrillas continues to be fierce in Arauca and the rebels maintain a strong presence in the region (Molinski 2012).

Table 1. HRPV victims by responsible group, 2001-2010

\begin{tabular}{lcc}
\hline Responsible group & No. of victims & \% of total \\
\hline Public forces & 1,523 & $47 \%$ \\
$\begin{array}{l}\text { Paramilitaries } \\
\text { Combined public forces- } \\
\text { paramilitaries }\end{array}$ & 474 & $15 \%$ \\
Total public forces-paramilitary & 161 & $5 \%$ \\
victims & $\mathbf{2 , 1 5 8}$ & $\mathbf{6 7 \%}$ \\
$\begin{array}{l}\text { FARC } \\
\text { ELN }\end{array}$ & 360 & $11 \%$ \\
Guerrilla (unspecified) & 150 & $5 \%$ \\
Total guerrilla victims & 76 & $2 \%$ \\
No information & $\mathbf{5 8 6}$ & $\mathbf{1 8 \%}$ \\
Other & 371 & $12 \%$ \\
Total (all) & 108 & $3 \%$ \\
\hline
\end{tabular}

Source: Data adapted from Banco de Datos de Derechos Humanos y Violencia Política del CINEP (2011) 


\section{Forced Displacement in Arauca}

Data from Acción Social (2011), ${ }^{18}$ a Colombian government agency, illustrate how forced displacement has been endemic in Arauca and intensified after 2001 (see Figure 4). According to these data, 1,059 people were forcibly displaced in 2000, rising to 1,546 people in 2001 and 6,071 in 2002. From 2002 to 2010, the annual range of IDPs was 3,468 to 11,648, much higher than in 2000. Therefore, as the military and paramilitaries began to consolidate their presence in Arauca, forced displacement intensified. Moreover, displacement peaked in the period 20062008, illustrating that security continued to decline for large swathes of Arauca's citizens throughout the 2000s.

Similar to HRPV data, of the 66,083 IDPs recorded in Arauca between 1998 and 2010, 88\% were displaced in the four municipalities under strong public forces-paramilitary control: $43 \%$ in Arauca Municipality, Arauquita and Saravena; $45 \%$ in Tame. ${ }^{19}$ With the exception of Tame, this demonstrates a high level of displacement where the Caño Limón oil complex is located and where the pipeline traverses. Moreover, given that these areas were controlled by the public forces and paramilitaries, these data support broader observations that the paramilitaries are responsible for the majority of forced displacement in Colombia ${ }^{20}$ and that the public armed forces are responsible for a large share. For instance, the military was responsible for two large episodes of collective forced displacement in Tame in April and May 2003, when, respectively, approximately 500 and over 350 people from indigenous communities were displaced from their homes (see CINEP 2011). ${ }^{21}$

\footnotetext{
${ }^{18}$ CINEP's data only include collective forced displacement and thus do not include the forced displacement of individuals/individual households, the latter being the long standing trend of forced displacement in Colombia (Lari 2007; Ibáñez and Velásquez 2009). Instead, data from Acción Social are used, the GOC agency responsible for recording IDP data during the period analyzed in this article. It is also important to note a drawback with these figures, namely, these data undoubtedly underreport the number of IDPs, which has been documented by numerous sources (Lari 2007; Hristov 2009; CODHES 2011; IDMC 2012, 2013). Notwithstanding their conservative nature, these data nevertheless demonstrate the intensity of forced displacement in Colombia's armed conflict. Forced displacement data can now be found at the GOC's Departmento para la Prosperidad Social.

${ }^{19}$ Six victims had no information regarding municipality.

${ }^{20}$ In this light, if individual forced displacement were recorded by CINEP, then HRPV victims attributable to the paramilitaries would be higher.

${ }^{21}$ This further highlights the conservative nature of GOC's displacement data, which record a total of only 343 indigenous IDPs in Tame in 2003.
} 


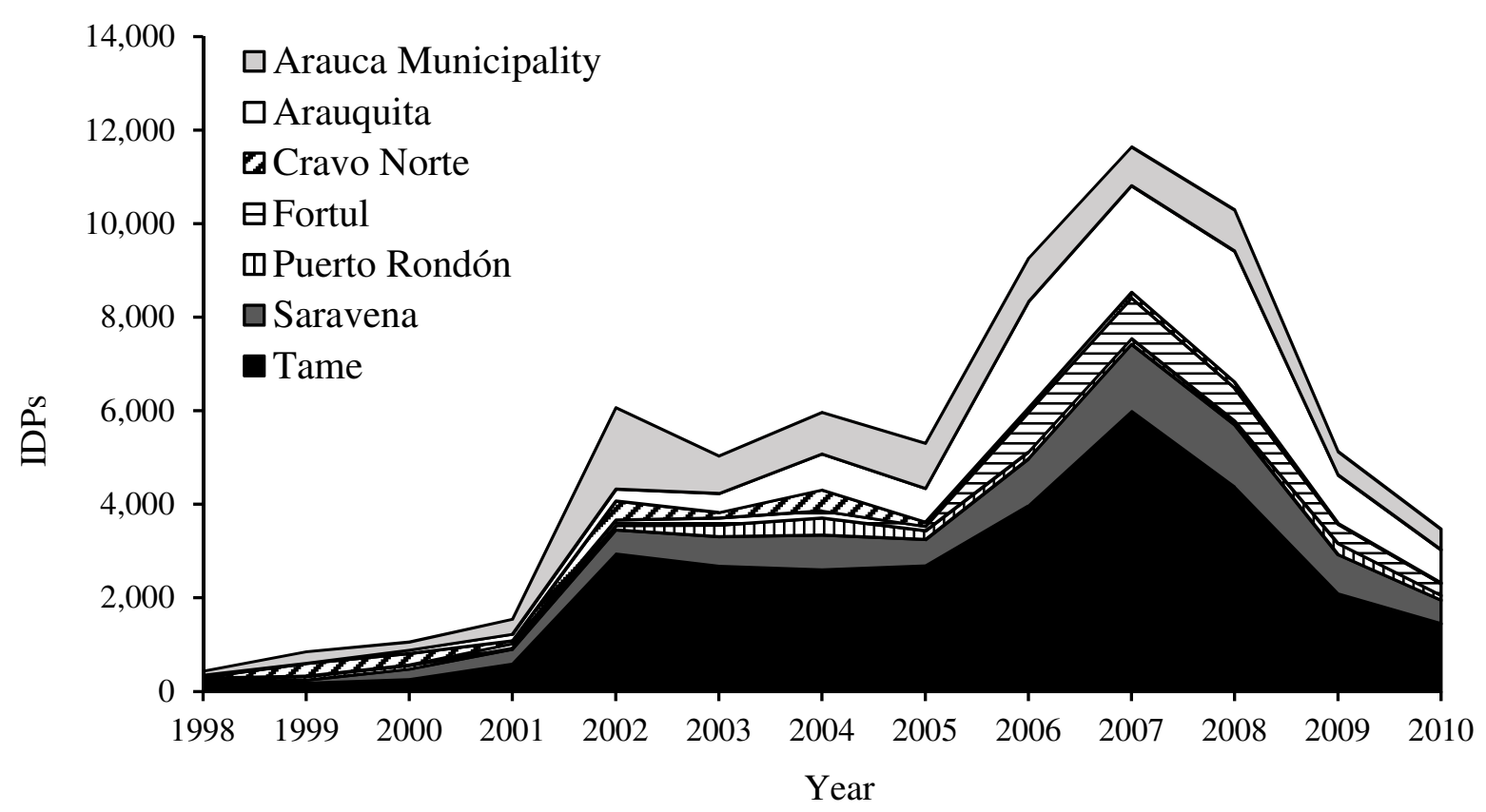

FIG 4. Displacement in Arauca by Municipality, 1998-2010

Source: Data adapted from Acción Social (2011)

\section{Rising Production and Exploration at Caño Limón and the Arauca Block}

Greater production and oil exploration have followed these periods of violence. At Caño Limón, the effect of reduced pipeline bombings was almost immediately evident: by 2002 OXY was producing twice as much oil at its 212 wells than in 2001 (Forero 2002). ${ }^{22}$ Production has also increased with greater exploration. As early as 2002, OXY signed new contracts with Ecopetrol to explore an additional three blocks covering 9,325 square miles (Forero 2002). In 2005, OXY drilled 40 new oil wells in the Caño Limón oilfield and the company continues to look for additional oil reserves in the region, an activity it avoided prior to 2004 due to safety concerns (GAO 2005:18-19). As discussed, these developments followed a period of intensifying violence between 2001 and 2004, including in municipalities of strategic importance to oil production at Caño Limón (Figures 3 and 4).

As Figure 5 shows, after a spike in 2002, displacement has remained consistently high in Arauca Municipality from 2003 to 2008, with an annual average of 884 IDPs during this time. In Arauquita, a spike in IDPs is recorded between 2006 and 2008, with an annual average of 2,449 IDPs during this period. From 2003 to 2008, 14,540 IDPs were recorded in these

\footnotetext{
${ }^{22}$ The Caño Limón facility can pump oil into storage tanks with a seven-day holding capacity (GAO 2005:16, footnote 20). Thus, with reduced pipeline attacks, production can continue as normal.
} 
municipalities, representing $72 \%$ of total IDPs recorded in the $1998-2010$ period in Arauca Municipality and Arauquita. In 2007, following these periods of intense violence, Pacific Rubiales, a Canadian oil corporation, agreed to explore potential oil reserves in the "Arauca Block," which is located in Arauca Municipality and immediately borders Arauquita (the block is approximately $60 \mathrm{~km}$ east of the Caño Limón field) (Petrotech Engineering 2007; Pacific Rubiales 2008:41; PR Newswire 2011). Displacement remained high after 2007 as exploration continued and suggests that the public armed forces and paramilitaries continued to expand their territorial control to protect oil infrastructure of strategic importance to the Arauca Block (as well as Caño Limón). This includes protection against attacks on electricity transmission towers in Arauquita, which leads to electricity blackouts in Arauquita, Arauca Municipality and Cravo Norte. In one attack in 2009, for instance, 100,000 people lost electricity and power was cut to oil facilities in these municipalities (Latin America Herald Tribune 2009; Semana 2009).

By 2011, exploratory oil drilling in the Arauca Block had generated a good deal of enthusiasm within Pacific Rubiales. As Ronald Pantin, Pacific Rubiales' CEO, states: "We are very encouraged by this first success in the Arauca Block as this represents an auspicious start of the activity in this brand new oil region, setting the path for new discoveries that will enlarge our resource base and ensure the long term growth of the block" (Pacific Rubiales 2011).

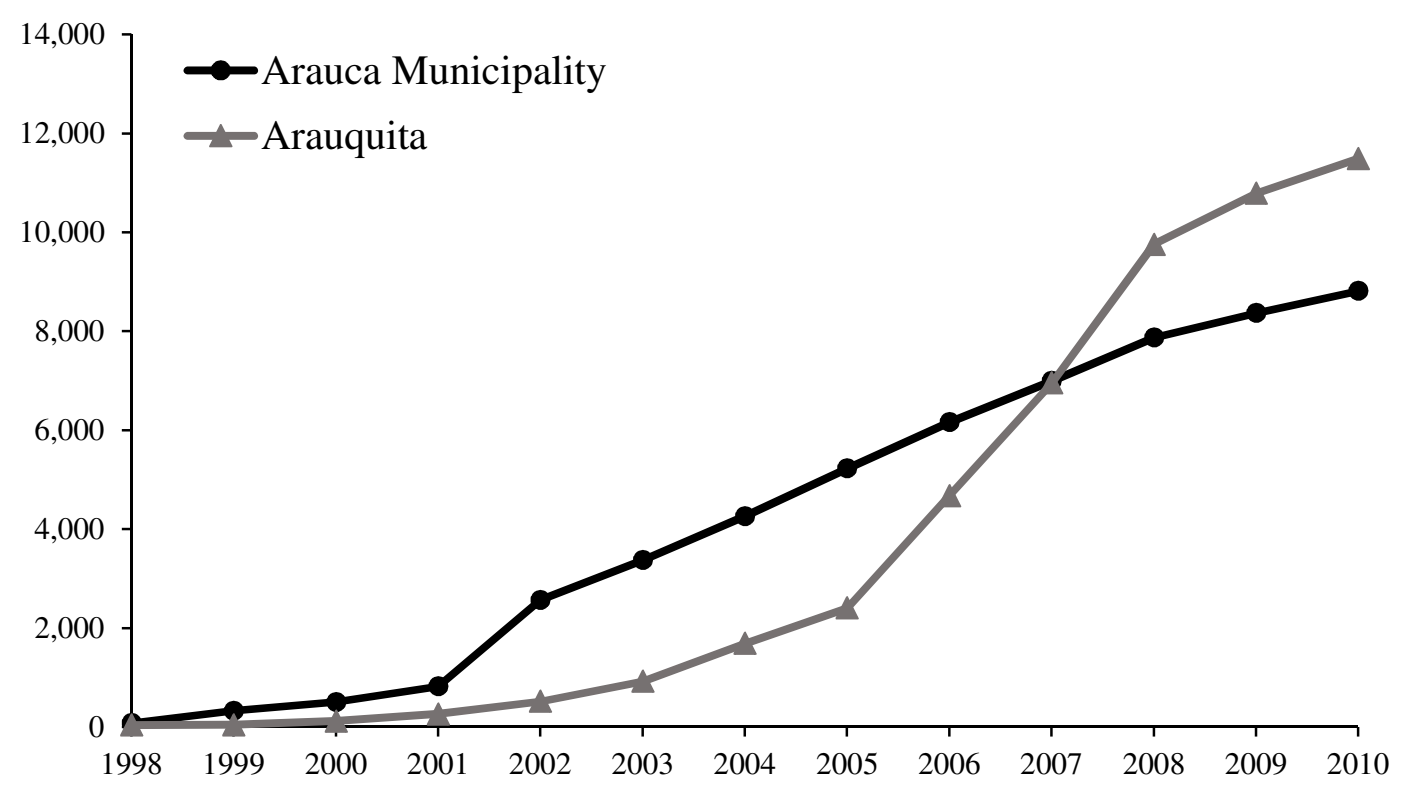

FIG 5. Displacement (cumulative) in Arauca Municipality and Arauquita, 1998-2010 Source: Data adapted from Acción Social (2011) 


\section{Tame: Capachos, the Bicentenario Pipeline and Indigenous groups}

As noted, the data above show acute violence in Tame. Crucially, the Capachos oilfield is located in this municipality and is very close to indigenous territory (Permanent Tribunal of Peoples 2007). On the one hand, as expected, on the whole violence against indigenous groups in Arauca has been endemic and forced displacement intensified from 2003 onwards (Figure 6). On the other hand, from a total of 1,381 indigenous IDPs recorded in Arauca between 1998 and 2010, 813 (59\%) were displaced in Tame. Notwithstanding the conservative nature of these figures, this represents $70 \%$ of Tame's total indigenous population (DANE 2010; author calculation).

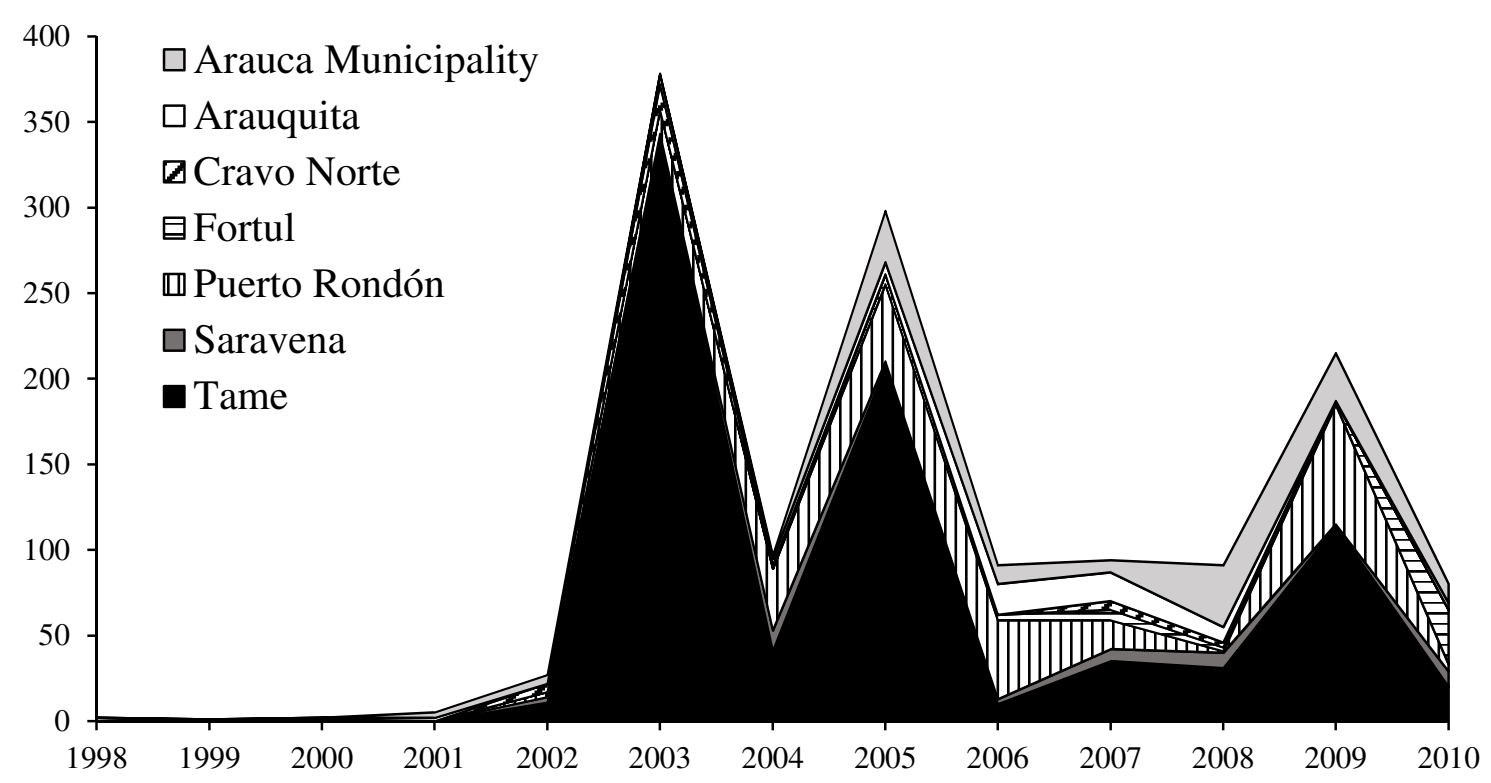

FIG 6. Displacement of Indigenous Groups in Arauca, 1998-2010

Source: Data adapted from Acción Social (2011)

In 2002, when the displacement of indigenous groups in Tame began to rise, Repsol, a Spanish oil corporation, announced the discovery of oil in the Capachos oilfield (see Amnesty International 2004:33). This was followed by spikes in the numbers of IDPs from indigenous groups in Tame, especially in 2003 (Figure 6). The data also show that $80 \%$ of displacement of indigenous groups in Tame occurred between 2002 and 2007. Such widespread displacement was observed by a UNHCR team, which noted in 2008 that "in some parts of the department, and especially around Tame, the countryside is almost empty" as people began fleeing the countryside to the cities with the arrival of armed groups (Verney 2008). In April 2008, following this intense period of forced displacement, Repsol's Capachos Sur field (in the Capachos Block) began production. The number of IDPs continued to rise until 2009, the year 
that Repsol found further oil discoveries in its Capachos Sur 1 well (Repsol 2009:152-3). ${ }^{23}$

In addition to greater exploration, major new infrastructure projects are under development in this region. This includes part of the $\$ 4.2$ billion Bicentenario pipeline, which, at a length of over 550 miles, will run from the department of Casanare to Coveñas. While the pipeline will be fully completed in late 2015, it currently runs northwards through Arauca, traversing the municipalities of Tame, Fortul and Saravena (where it currently connects to the Caño LimónCoveñas pipeline; Smith 2012; Delgado 2014). The pipeline was announced in 2010 when Ecopetrol sought private-sector partners for its construction (Pipeline and Gas Journal 2010). Construction began in 2011 and the first phase of the project (linking it to the Caño LimónCoveñas pipeline in Arauca) was completed in November 2013. The announcement (2010) and commencement of construction (2011) of the pipeline followed a particularly high level of forced displacement in Tame, Fortul and Saravena, namely, in the 2006-2009 period. As Table 2 shows, $57 \%$ of the total IDPs recorded in these municipalities during the entire 1998-2010 period were displaced in the four-year period 2006-2009.

Table 2. Forced displacement in Fortul, Saravena and Tame

\begin{tabular}{lcc}
\hline Municipality & $\begin{array}{c}\text { Total IDPs } \\
\mathbf{1 9 9 8 - 2 0 1 0}\end{array}$ & $\begin{array}{c}\text { IDPs 2006-2009 }(\% \\
\text { of total in brackets) }\end{array}$ \\
\hline Fortul & 3,728 & $2,823(76 \%)$ \\
Saravena & 8,243 & $4,624(56 \%)$ \\
Tame & 29,932 & $16,413(55 \%)$ \\
Total & 41,903 & $23,862(57 \%)$ \\
\hline
\end{tabular}

Source: Data adapted from Acción Social (2011)

To summarize, civil war violence has been high in municipalities of strategic importance to oil interests in the area, with episodes of violence followed by greater oil production, oil exploration and the construction of infrastructure. The data above thus support critical arguments that forced displacement has "cleared" land of people in these strategic areas, including indigenous groups, which has given corporations access to land to explore and drill for oil. Without this violence, this land would have otherwise been unavailable to oil corporations. Moreover, this evidence supports claims that violence creates "buffer zones" to

\footnotetext{
${ }^{23}$ The oilfield is now operated by Ecopetrol, which announced a deal in May 2014 to sell a 50 per cent stake in the Capachos oil block to Parex Resources inc.. Drilling is due to begin in 2015, subject to regulatory approval (Reuters 2014).
} 
protect oil infrastructure and that violence has helped silence opposition to oil interests in the area, especially with regard to the vocal opposition of indigenous groups. The data presented above thus suggest that rising levels of violence have indeed enabled the public forces and paramilitaries to achieve territorial control in areas of strategic and economic importance in Arauca, which has benefitted oil interests in the region. Once this territorial control was largely achieved, broader levels of HRPV victims and forced displacement subsequently declined in Arauca, especially during the latter period of 2001-2010. ${ }^{24}$ Nevertheless, the analysis above shows that after initial increases in conflict intensity, greater oil production, exploration and investment have continued during periods of intense violence.

\section{WIDER IMPLICATIONS ${ }^{25}$}

\section{Beyond Arauca}

Clear parallels can be drawn between the Arauca case and other important oil producing regions of Colombia. A case in point is the department of Meta, Colombia's largest oil producing region accounting for $47 \%$ of the country's total oil production (Reuters 2011). Collectively, Meta and Arauca accounted for $56 \%$ of Colombia's total oil production in 2011. As with Arauca, levels of violence, including forced displacement, have intensified in Meta during periods of rising investment in Colombia's oil industry (Figure 7). Violence has been particularly high in the municipality of Puerto Gaitán, where the majority of Meta's oil production is concentrated (Gobernacion del Meta n.d.). Between 1998 and 2010, 3,252 people were forcibly displaced in Puerto Gaitán, representing 21\% of the municipality's total population (DANE, 2008; Acción Social 2011). Moreover, of the 4,207 HRPV victims recorded in Meta in the 2001-2010 period, $72 \%$ were victims of public forces-paramilitary violence (CINEP 2011).

\footnotetext{
${ }^{24}$ Longer-term patterns in Colombia's conflict also show that levels of violence vary across different periods (see data from UCDP 2013). Therefore, falling levels of violence in Arauca may rise again in the future. For instance, pipeline bombings have increased in Colombia in recent years (Ministerio de Defensa Nacional 2014) and a rise in violence may follow.

25 The following HRPV data for Meta and Casanare have been further coded by this author. Data on forced displacement have been collated and compiled by this author.
} 


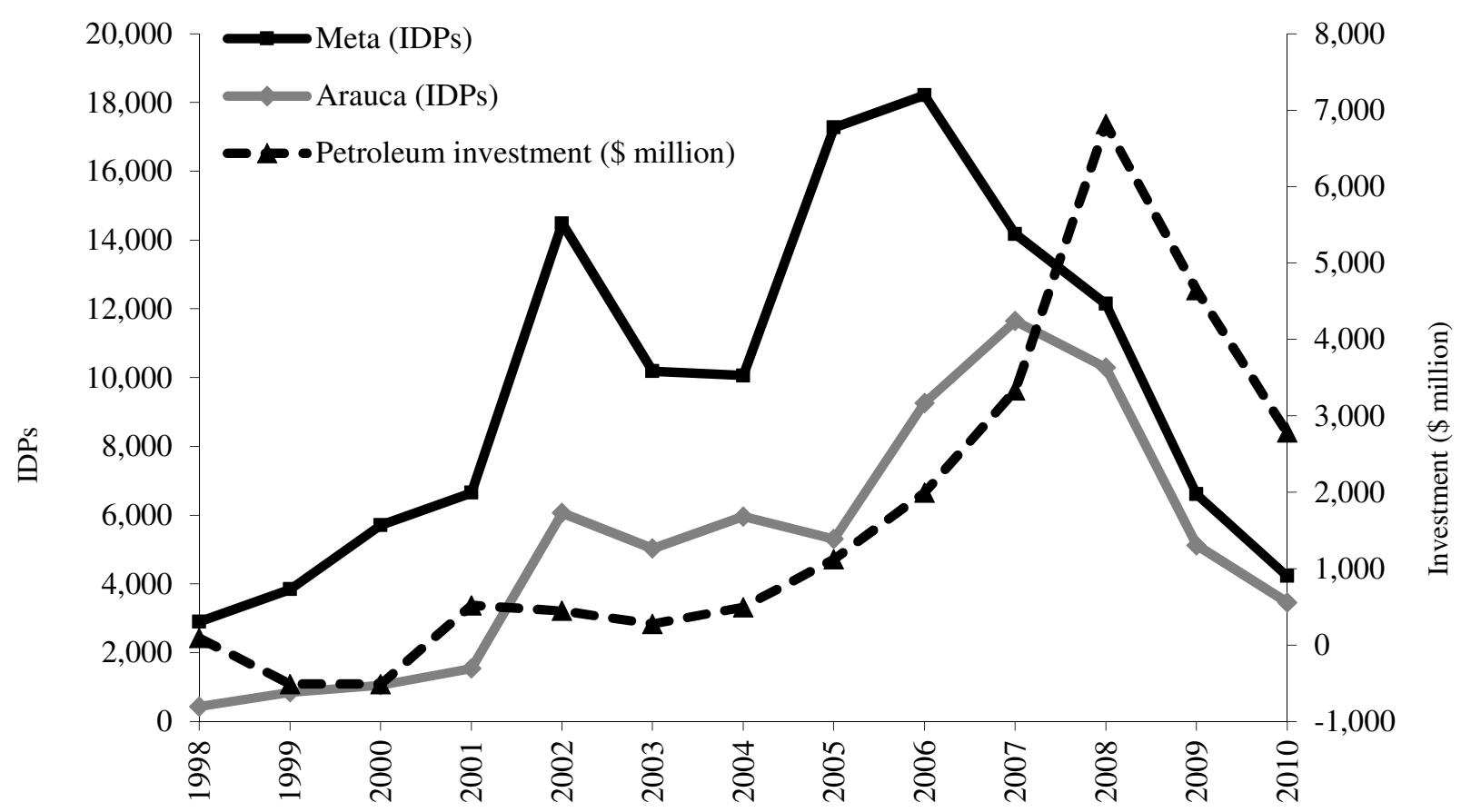

FIG 7. IDPs in Meta and Arauca; Investment in Colombia's Petroleum Sector Source: Data adapted from Unidad de Planeación Minero Energética, n.d.; Acción Social, 2011

Similar trends are evident in the department of Casanare, the second largest oil producing department of Colombia, contributing 16\% to Colombia's total oil production in 2011 (Reuters 2011). Casanare's most important oil municipalities, Tauramena, Aguazul and Yopal, have experienced high levels of forced displacement: 8,584 people have been displaced in these municipalities between 1998 and 2010 (Acción Social 2011). Of the 614 HRPV victims recorded in Casanare, $77 \%$ were victims of public armed forces-paramilitary violence (CINEP 2011). Widespread violence is also evident in other oil producing regions of Colombia, including some of the most violent regions of the country. A case in point is Putumayo, where forced displacement is an acute problem and where trade unionists representing oil workers have been violently targeted (UNHCR 2008; Justice for Colombia 2011).

\section{Beyond Colombia and Oil}

This paper subscribes to the view that civil wars are individually complex and the economic effects of violence can be disparate. Thus, while it would be naïve to argue that political violence is always conducive to higher FDI inflows, it would be equally naïve to suggest that all types of civil war violence are inimical to inward flows of FDI. In this light, this article does not aim to make broad generalizations regarding civil war and FDI based solely on the 
Colombian case study. Indeed, scholars advocating the use of large-N statistical models to analyze civil wars may find that characteristics inherent to Colombia's civil war make extrapolating more general trends difficult.

For instance, Colombia's conflict has persisted for over 50 years. One argument may be that the GOC has become war-weary following the attrition of civil war. Such a proposition resonates with Blanton and Apodaca's (2007) study, which suggests that FDI inflows are associated with lower intensity conflicts as states that are exposed to FDI have an interest to settle armed conflicts. Regime type may also be a factor, as Colombia may be perceived to be democratic with, for example, a polity score of +7 (from a maximum of +10 for a "full democracy") in 2008 (Marshall, Gurr and Jaggers 2014). This could make Colombia difficult to compare with, say, a dictatorial regime. There is also a wealth of research linking primary commodity exports such as oil with civil war (for a classic study, see Collier and Hoeffler 2004).

Nevertheless, the Colombian case equally raises questions about large- $\mathrm{N}$ investigations into civil war, further highlighting the disjuncture between large-N studies and case study analyses. As we have seen, contrary to Blanton and Apodaca's conclusion, the intensity of Colombia's civil war has worsened as the conflict has matured, particularly during the 2000s. During this time, inward FDI flows strongly increased. It is also worth noting that scholarly research into regime type and civil war has produced highly inconsistent results that can be entirely contradictory (see Sambanis 2004; Cramer 2006). Polity scores - often used for such analyses - have also been criticized (Gleditsch and Ward 1997). Furthermore, although a discussion does not fit the scope of this article, the democratic nature of Colombia can be criticized given the very high levels of political violence in the country (for example, Livingstone 2003; Murillo 2004; Stokes 2005; Hylton 2006; Hristov 2009; Brittain 2010).

Emerging scholarship also observes that the ability of civil war economies to attract inward flows of FDI is not limited to the oil sector or primary commodities. Indeed, while firms operating in the extraction of natural resources may be bound by geography, firms in the service sector - which are much less bound by geography - also invest in civil war economies (Mihalache-O'keef and Vashchilko 2010). Similarly, Driffield, Jones and Crotty (2013) find that firms in high-technology and manufacturing industries are also likely to invest in conflict zones. In light of the above points, while this article does not attempt to make broad generalizations, it is nevertheless hoped that the analysis presented in this article may act as a 
modest platform to better understand how other civil wars interact with FDI.

\section{CONCLUSION}

Discordant with the "development in reverse logic," nascent scholarship indicates that FDI is entering countries with civil wars (Mihalache-O'keef and Vashchilko 2010; Driffield, Jones and Crotty 2013). The analysis presented in this article suggests that we should not assume that FDI is attracted to these economies in spite of violence or that FDI flows only to peaceful regions of countries with civil wars. In the Colombian case, FDI has flowed to areas of economic interest following (and often continuing during) periods of intensifying civil war violence. Furthermore, the assumption that political violence, especially civil war, exclusively presents risks to investors is problematic.

In Colombia, violence perpetrated by central actors of the conflict - the public forces and paramilitaries - has ensured access to land for oil exploration, has facilitated low labor costs by targeting trade unions and other civil groups, has stymied opposition to further oil exploration, and has protected and minimized threats to vital infrastructure in Arauca. Therefore, levels of FDI and the resultant economic growth may have been lower in Colombia in the absence of public forces-paramilitary violence. Moreover, while Hristov (2009:206) argues that economic elites can enrich themselves through certain types of violence (for instance, paramilitary violence) in Colombia, even during periods of economic stagnation, the broader implication of this article is that certain types of civil war violence can bolster aggregate measures of economic growth by facilitating increases of inward FDI.

In light of the observations discussed above, a central conclusion of this paper is that civil war violence should not be treated as homogeneous. In the Colombian case, violence perpetrated by the public forces and paramilitaries is qualitatively different from the violence perpetrated left-wing rebels, the latter typically targeting the economic interests of domestic and foreign investors. One implication that can be drawn from this article, therefore, is that violence can facilitate inward FDI in civil war economies if armed actors sympathetic to the interests of foreign capital are able to achieve territorial control in strategically important regions. In Colombia, this territorial control has been achieved despite the presence of powerful and wellfunded left-wing rebel groups, which have intensified their military campaigns to contest the expansion of the public armed forces and paramilitaries. 
A final point needs to be made. As Cramer (2006:47) implores, the acceptance that economic development can be linked to conflict should not lead to the indulgence of violence or a leaning "towards romantic consolidation, which may then be distorted to justify cruel actions" (Cramer 2006:47). Instead, this acceptance can serve an entirely different function by highlighting that, while progress is something worth struggling for, "The idea needs to be tempered by a sharper awareness that it will not erase the essential sources of suffering in society" (Cramer 2006:47). Moreover, as Thomson (2011:327) argues, sectors of the economy that benefit from violence may represent "progress" in terms of job creation and foreign exchange earnings; however, for displaced communities, this type of violent development constitutes the obverse of "progress." This is especially true given the acute welfare losses experienced by the victims of forced displacement (e.g., see Ibáñez and Moya 2010).

\section{APPENDIX A}

\section{CINEP's Data and Coding}

CINEP records a range of human rights violations and political violence, which include: extrajudicial killings, disappearances, collective displacement, torture, arbitrary detention, individual and collective threats, kidnapping, sexual violence, etc. CINEP records these violations by event and, as a result, multiple instances of human rights violations and political violence can be recorded in a single event. Some commentators have thus argued that the data show inflated numbers of human rights violations (O'Grady 2004). Supporters of the Colombian government, namely, Mary Anastasia O'Grady (2004), have also alleged that CINEP exclusively concentrates on violations perpetrated by the Colombian state or statesponsored actors. This claim is manifestly untrue and the data indeed include human rights violations and political violence committed by the guerrillas (see CINEP 2008). Moreover, Holmes, Gutierrez de Piñeres and Curtin (2008:68-71) observed a high correlation between Colombian government statistics on terrorism and CINEP figures on guerrilla violence, which provides confidence in the latter's data. While it is entirely valid to analyze instances of multiple human rights violations per event, for the purpose of analysis in this article, I have further coded CINEP's data to include only the victims of violent episodes, instead of the number of violent acts per event. The problem of over-reporting human rights violations and political violence is thus eliminated. (It is worth noting that the situation in Colombia is likely to be worse than CINEP's data suggest given that human rights violations are often under reported by victims; see Holmes, Gutierrez de Piñeres and Curtin 2008:71; Hough 2011.) It is 
also worth mentioning CERAC's (n.d.) dataset, which is based on CINEP's data. However, this dataset has been further coded to show actions deemed to be "battle-related deaths" and "battleevents" and is only available at the department level. Instead, the data in this article consider victims of all categories of violence committed by all warring parties. To do this, I have further coded CINEP's data to better illustrate the authors of violent episodes. Pertinently, CINEP's data do not employ a consolidated code or category to identify authors of a particular event. For example, a violent episode perpetrated by Colombia's public forces can be recorded as Military Forces, Police, Air Force, Army, and so on. Multiple authors (for example, Military Forces, Police and Paramilitaries) can also be recorded for a single event. Therefore, in addition to coding CINEP's data by victim, I have further coded the data into consolidated codes for the authors of violence. More specifically: (1) Public Forces, (2) Paramilitaries, (3) Combined Public Forces-Paramilitaries, (4) FARC, (5) ELN, (6) Guerrillas (unspecified), (7) No information (as coded by CINEP), (8) Other (for instance, combatants, foreign agents, etc.). I have also compiled this data by year, author, number of victims, department and municipality.

\section{APPENDIX B \\ CINEP's Data and the "False Positive" Scandal}

The so-called "false positives" scandal - the widespread extrajudicial killings of civilians by the military, who disguised and presented these deaths as guerrilla insurgents killed in combat - should not have a strong impact on the figures used in this article. Of the 3,896 "false positive" executions recorded throughout Colombia between 1986 and 2013, 85 were recorded in Arauca (2\% of the total; see Fiscalía 2013; see also Colombia Reports 2013). While it is unclear how many of these deaths occurred during the 2001-2010 period analyzed in this article, inclusion of the full 85 deaths would augment the proportion HRPV victims of public forces violence from $47 \%$ to $49 \%$. In this light, and given the difficulties in establishing when these "false positive" deaths occurred, compounded with possible overlap with extrajudicial executions recorded in CINEP's data, these deaths are excluded from the data.

\section{APPENDIX C}

\section{Guerrilla Data: The Conflict between the FARC and the ELN}

While sharing common enemies, namely, the armed forces and paramilitary groups, relations between the FARC and ELN in Arauca have hardly been harmonious. Indeed, the guerrilla groups have often targeted each other in the region, more specifically during the 2005-2010 
period (Corporación Nuevo Arco Iris 2012). In 2009, the FARC and ELN reached an agreement to end this conflict on a national level; in September 2010, this was implemented in Arauca when the two groups agreed to a truce in the region (Colombia Reports 2010; Corporación Nuevo Arco Iris 2012).

According to CINEP's data, the intensification of conflict between the FARC and ELN in Arauca during 2005-2010 did not lead to a spike in guerrilla victims of HRPV when the 20012010 period is considered. In fact, CINEP's data show that the majority of guerrilla HRPV victims were recorded before 2005-2010. As Table 3 shows, in the four-year period between 2001 and 2004, total guerrilla violence was responsible for 415 victims (71\% of total guerrilla violence), compared to 171 victims (29\%) in the five-year period 2005-2010 (see Table 3).

Table 3. Guerrilla HRPV victims, 2001-2010

\begin{tabular}{lcc}
\hline Period & No. of victims & \% of total \\
\hline $2001-2004$ & 415 & $71 \%$ \\
$2005-2010$ & 171 & $29 \%$ \\
Total guerrilla victims (2001-2010) & $\mathbf{5 8 6}$ & $\mathbf{1 0 0 \%}$
\end{tabular}

Source: Data adapted from Banco de Datos de Derechos Humanos y Violencia Política del CINEP (2011)

\section{REFERENCES}

ACCIÓN SOCIAL (2011) Registro Único De Población Desplazada: Indice General de Tabulados de Población Despezada. Available at: http://www.accionsocial.gov.co/EstadisticasDesplazados/ (accessed 11 September 2012).

AMAZON WATCH. (2011) Colombia's U'wa Face New Threats. U'wa Indigenous Group Confront New Threats to Their Lives and Territory <http://amazonwatch.org/news/2011/0115-colombias-uwa-face-new-threats> (2012, August 9).

AMAZON WATCH. (2002) Civil Conflict and Indigenous Peoples in Colombia. $<$ http://amazonwatch.org/news/2002/0301-civil-conflict-and-indigenous-peoples-in- 
colombia>

AMNESTY INTERNATIONAL. (2002) Colombia Security at What Cost? The Government's Failure to Confront the Human Rights Crisis. New York: Amnesty International.

AMNESTY INTERNATIONAL. (2004) Colombia: Laboratory of War - Repression and Violence in Arauca. New York: Amnesty International. <http://www.amnesty.org/en/library/info/AMR23/004/2004> (2012, September 10).

ÁVILA MARTÍNEZ, ARIEL FERNANDO. (2010) De la guerra de "Jojoy" a la guerra de “Cano.” In: Corporación Nuevo Arco Iris, Balance de las FARC Después de “Jojoy” y los Nuevos Carteles de Narcotráfico. Informe Seguridad y Conflicto Armado. N.p.: Corporación Nuevo Arco Iris.

ÁVILA MARTÍNEZ, ARIEL FERNANDO. (2011) Guerrillas, FARC y ELN: Acciones de Interferencia para las Elecciones de 2011. Mapas y Factores de Riesgo Electoral Elecciones Locales y Regionales, Octubre 2011. Bogotá, DC: Misión de Observación Electoral.

AZAM, JEAN-PAUL, AND ANKE HOEFFLER. 2002. Violence Against Civilians in Civil Wars: Looting or Terror? Journal of Peace Research 39(4):461-85.

BANCO DE LA REPÚBLICA (n.d.) Flujos de inversión directa - balanza de pagos. Inversión extranjera directa en Colombia. <http://www.banrep.gov.co/es/inversiondirecta>.

BARBIERI, KATHERINE AND RAFAEL REUVENY. (2005) Economic Globalization and Civil War. The Journal of Politics 67(4):1228-47.

BLANTON, ROBERT G. AND CLAIR APODACA. (2007) Economic Globalization and Violent Civil Conflict: Is Openness a Pathway to Peace? The Social Science Journal 44:599-619.

BLOOMBERG. (2011) Colombia Sees Record Oil Output as Billionaire Slim, China Seek Reserves. Bloomberg. < http://www.bloomberg.com/news/2011-03-16/colombiaexpects-record-oil-production-as-carlos-slim-china-seek-reserves.html> $(2014$, August 15). 
BODEA, CRISTINA AND IBRAHIM A. ELBADAWI. (2008) Political Violence and Economic Growth, Policy Research Working Paper 4692. New York: World Bank.

BRITTAIN, JAMES J. (2010) Revolutionary and Social Change in Colombia: The Origin and Direction of the FARC-EP. London: Pluto Press.

BUHAUG, HALVARD AND RØD, JAN K. (2006) Local Determinants of African Civil Wars, 1970-2001. Political Geography 25:315-35.

BUSSE, MATTHIAS, AND CARSTEN HEFEKER. (2007) Political Risk, Institutions and Foreign Direct Investment. European Journal of Political Economy 23:397-412

CEDERMAN, LARS-ERIK AND KRISTIAN SKREDE GLEDITSCH. (2009) Introduction to Special Issue on Disaggregating Civil Wars. Journal of Conflict Resolution 53:48795.

CENTRO DE INVESTIGACIÓN Y EDUCACIÓN POPULAR (CINEP). (2011) Banco de Datos de Derechos Humanos y Violencia Política del CINEP $<$ http://www.nocheyniebla.org/>.

CENTRO DE INVESTIGACIÓN Y EDUCACIÓN POPULAR (CINEP). (2008) Marco Conceptual: Banco de Datos de Derechos Humanos y Violencia Política. Bogotá: CINEP.

\section{CENTRO DE RECURSOS PARA EL ANÁLISIS DE CONFLICTOS (CERAC). (n.d.)} Database of the Armed Conflict in Colombia. <http://www.cerac.org.co/es/recursos/datosconflictoscolombia/> (2013, May 11).

COLEMAN, LARA. (2007) The Gendered Violence of Development: Imaginative Geographies of Exclusion in the Imposition of Neo-Liberal Capitalism. British Journal of Politics \& International Relations 9(2):204-19.

COLLIER, PAUL. (1999) On the Economic Consequences of Civil War. Oxford Economic Papers 51:168-83.

COLLIER, PAUL. (2000) “Doing Well Out of War." In Greed and Grievance: Economic Agendas in Civil Wars, edited by Mats Berdal and David Malone, pp. 91-111. Boulder, CO: Lynne Rienner. 
COLLIER, PAUL AND ANKE HOEFFLER. (2004) Greed and Grievance in Civil War. Oxford Economic Papers 56:563-595.

COLLIER, PAUL AND MARGUERITE DUPONCHEL. (2013) The Economic Legacy of Civil War: Firm-Level Evidence from Sierra Leone. Journal of Conflict Resolution 57(1):65-88.

COLLIER, PAUL; LANI ELLIOT, HÅVARD HEGRE, ANKE HOEFFLER, MARTA REYNAL-QUEROL AND NICHOLAS SAMBANIS. (2003) Breaking the Conflict Trap: Civil War and Development Policy. Washington, DC.: World Bank.

COLOMBIAN NGO PLATFORM. (2008) Informe Para el Examen Periódico Universal de Colombia. <//www.internaldisplacement.org/8025708F004CE90B/(httpDocuments)/F17E35781C31C18FC1257 4C7004EBE23/\$file/Informe-final-para-el-EPU_Colombia.pdf> (2010, July 28).

COLOMBIA REPORTS. (2013) Colombia Military Murdered 3900 Civilians to Inflate Effectiveness: Prosecution. <http://colombiareports.com/colombia-military-murdered3900-civilians-to-inflate-success-public-prosecutors/> (2013, August 14).

COLOMBIA REPORTS. (2010) FARC and ELN Make Peace in Arauca. $<$ http://colombiareports.com/farc-and-eln-make-peace/> (2013, August 14).

COMISIÓN DE SEGUIMIENTO A LAS POLÍTICAS PÚBLICAS SOBRE DESPLAZAMIENTO FORZADO. (2010) III Encuestra Nacional de Verificación de los Derechos de la Poblacion Desplazada 2010. Bogotá, DC: Comisión de Seguimiento.

COMISIÓN DE SEGUIMIENTO A LAS POLÍTICAS PÚBLICAS SOBRE DESPLAZAMIENTO FORZADO. (2009) Proceso Nacional de Verificación. Décimotercer Informe. el Desplazamiento Forzado en el Caso de la Comunidad Afrocolombiana. Bogotá, DC: Comisión de Seguimiento.

COMITÉ PERMANENTE POR LA DEFENSA DE LOS DERECHOS HUMANOS, SECCIONAL ARAUCA (CPDH-Arauca). (2012) Atropellos de la Multinacional OXY Contra Campesinos de Arauca. <http://prensarural.org/spip/spip.php?article7976> (2012, August 9). 


\section{CONSULTORÍA PARA LOS DERECHOS HUMANOS Y EL DESPLAZAMIENTO}

(CODHES). (2009) Víctimas Emergentes. Bogotá: Boletín Informativo de la Consultoría para los Derechos Humanos y el Deplazamiento.

\section{CONSULTORÍA PARA LOS DERECHOS HUMANOS Y EL DESPLAZAMIENTO}

(CODHES). (2011) De la Seguridad a la Prosperidad Democrática en Medio del

Conflicto. Bogotá: Boletín Informativo de la Consultoría para los Derechos Humanos y el Deplazamiento.

CORPORACIÓN NUEVO ARCO IRIS. (2012) Arauca: El Gran Fortín del ELN. <http://www.arcoiris.com.co/2012/04/arauca-el-gran-fortin-del-eln/> (2014, March 21).

CRAMER, CHRISTOPHER. (2006) Civil War is Not a Stupid Thing: Accounting for Violence in Developing Countries. London: Hurst \& Co.

CRAMER, CHRISTOPHER (2002) Homo Economicus Goes to War: Methodological Individualism, Rational Choice and the Political Economy of War. World Development 30 (11):1845-64.

DELGADO, DIANA (2014) Colombia's Bicentenario Pipeline to Startup in late 2015. $<$ http://www.bicentenario.com.co/news.php?idnews=62> (2014, March 25).

DEPARTAMENTO ADMINISTRATIVO NACIONAL DE ESTADÍSTICA (DANE). (2008) Censo General 2005: Nivel Nacional. Bogotá, DC: República de Colombia.

DEPARTAMENTO ADMINISTRATIVO NACIONAL DE ESTADÍSTICA (DANE). (2010) Boletín. Censo general 2005. Perfil: Tame. Bogotá, D.C.: República de Colombia.

DRIFFIELD, NIGEL, CHRIS JONES, AND JO CROTTY. (2013) International Business Research and Risky Investments: An Analysis of FDI in Conflict Zones. International Business Review 22:140-155.

DUDLEY, STEVEN. (2002) War in Colombia's Oilfields: Washington's counterinsurgency aid will be a big boost to Occidental Petroleum. The Nation 5/12 August: 28-31.

ESCOBAR, ARTURO. (2004) Beyond the Third World: Imperial Globality, Global Coloniality and Anti-Globalisation Social Movements. Third World Quarterly 
25(1):207-30.

FISCALÍA. (2013) Solicitud de Información - Colombia Reports.

$<$ https://docs.google.com/file/d/1KfhKnlKMXbgdbQ7uMCXYvFxyyJhVFKnJRu651_ JyFd_vd8CazMSJXSYgUHYg/edit?pli=1> (2013, August 14).

FORERO, JUAN. (2002) New Role for US in Colombia: Protecting a Vital Oil Pipeline. <http://www.nytimes.com/2002/10/04/international/americas/04COLO.html> (2014, August 14).

GARCÍA CARRIZOSA, RAÚL EDUARDO. (2008) Indicadores de Gestion y Estadísticas de la Industria a 31 de diciembre de 2007. N.p.: Agencia Nacional de Hidrocarburos Colombia.

GLEDITSCH, KRISTIAN SKREDE, AND MICHAEL D. WARD. (1997) Double Take: A Reexamination of Democracy and Autocracy in Modern Polities. Journal of Conflict Resolution 41(3):361-83.

GLOBERMAN, STEVEN, AND DANIEL SHAPIRO. (2003) Governance Infrastructure and US Foreign Direct Investment. Journal of International Business Studies 34(1):19-39.

GOBIERNO DE COLOMBIA. (2003) Política de Defensa y Seguridad Democrática. Bogotá, DC: Presidencia de la República, Ministerio de Defensa Nacional.

GOBERNACION DEL META (n.d.) Caracterización Municipio de Puerto Gaitan 2009. <http://www.siid.gov.co/siid/forms/documentos/Microsoft\%20Word\%20-\%20PUERT O\%20GAITAN.pdf> (2012, December 19).

GRAJALES, JACOBO. (2011) The Rifle and the Title: Paramilitary Violence, Land Grab and Land Control in Colombia. Journal of Peasant Studies 38(4):771-92.

GUTIÉRREZ SANÍN, FRANCISCO. (2004) Criminal Rebels? A Discussion of Civil War and Criminality from the Colombian Experience. Politics \& Society 32(2):257-85.

GUTIÉRREZ SANÍN, FRANCISCO. (2008) Telling the Difference: Guerrillas and Paramilitaries in the Colombian War. Politics \& Society 36(1):3-34.

HARVEY, DAVID. (2003) The New Imperialism. Oxford: Oxford University Press. 
HEGRE, HÅVARD, GUDRUN ØSTBY, AND CLIONADH RALEIGH. (2009) Poverty and Civil War Events: A Disaggregated Study of Liberia. Journal of Conflict Resolution 53(4):598-623.

HILL, DAVID. (2014) Will the U'was Be Forced to Threaten to Commit Mass Suicide Again? The Guardian <http://www.theguardian.com/environment/andes-to-theamazon/2014/jun/17/will-uwas-forced-threaten-commit-mass-suicide-again > (2014, August 8).

HOLMES, JENNIFER S., SHEILA AMIN GUTIERREZ DE PIÑERES AND KEVIN M. CURTIN. (2008) Drugs, and Development in Colombia. Austin, TX: University of Texas Press.

HOUGH, PHILLIP A. (2011) Guerrilla Insurgency as Organized Crime: Explaining the Socalled "Political Involution" of the Revolutionary Armed Forces of Colombia. Politics \& Society 39(3):379-414.

HRISTOV, JASMIN. (2009) Blood and Capital: The Paramilitarization of Colombia. Toronto, Canada: Between the Lines.

HUMAN RIGHTS WATCH. (2010) Paramilitaries' Heirs: the New Face of Violence in Colombia. New York: Human Rights Watch.

HUMAN RIGHTS WATCH. (2005) Smoke and Mirrors: Colombia's Demobilization of Paramilitary Groups. New York: Human Rights Watch.

HYLTON, FORREST. (2006) Evil Hour in Colombia. London: Verso.

IBÁÑEZ, ANA M., AND CARLOS E VÉLEZ. (2008) Civil Conflict and Forced Migration: The Micro Determinants and Welfare Losses of Displacement in Colombia. World Development 36(4):659-76.

INTERNAL DISPLACEMENT MONITORING CENTRE (IDMC). (2009) Colombia: New Displacement Continues, Response Still Ineffective. A Profile of the Internal Displacement Situation. Geneva: IDMC.

INTERNAL DISPLACEMENT MONITORING CENTRE (IDMC). (2012) Global Overview 2011: People Internally Displaced by Conflict and Violence. Geneva: IDMC. 
INTERNATIONAL CRISIS GROUP. (2009) Ending Colombia's FARC Conflict: Dealing the Right Card. Brussels, Belgium: ICG.

INTERNATIONAL TRADE UNION CONFEDERATION (ITUC). (2007) Colombia - 2007. $<$ http://survey07.ituc-csi.org/getcountry.php?IDCountry=COL\&IDLang=EN> (2012, July 13).

INTERNATIONAL TRADE UNION CONFEDERATION (ITUC). (2012) International Trade Union Confederation (ITUC). 2012e. Colombia - 2012. In practice. <http://survey.ituc-csi.org/Colombia.html\#tabs-4> (2012, September 11).

ISACSON, ADAM. (2003) Washington's "New War” in Colombia: The war on drugs meets the war on terror. NACLA Report on the Americas 36(5): 13-45.

JAKOBSEN, JO, AND INDRA DE SOYSA. (2006) Do Foreign Investors Punish Democracy? Theory and Empirics, 1984-2001. Kyklos 59(3):383-410.

JUST THE FACTS. (2012) US Aid to Colombia, All Programs, 2000-2012. $<$ http://justf.org/Country?country=Colombia\&year $1=2000 \&$ year2=2012\&funding $=\mathrm{Al}$ $1+$ Programs $\& x=64 \& y=3>(2012$, September 10).

JUSTICE FOR COLOMBIA. (2011) Putumayo Trade Unions Threatened by Army and Paramilitaries. <http://www.justiceforcolombia.org/news/article/1019/putumayotrade-unions-threatened-by-army-and-paramilitaries> (2012, December 20).

JUSTICE FOR COLOMBIA. (2013a) Death Threats Against USO Oil Workers. < http://www.justiceforcolombia.org/news/article/1360/death-threats-against-uso-oilworkers> (2014, August 8).

JUSTICE FOR COLOMBIA. (2013b) Paramilitary Threats Against Oil Workers Union Intensifies. <http://www.justiceforcolombia.org/news/article/1428/paramilitarythreats-against-oil-workers-union-intensifies> (2014, August 8).

KALDOR, MARY. (2013) In Defence of New Wars. Stability 2(1):1-16.

KRAUL, CHRIS. (2011) Colombia is a rising oil exporter to US: The South American nation now ranks 10th among those sending crude our way. Los Angeles Times. <http://articles.latimes.com/2011/apr/07/business/la-fi-Colombia-oil-20110407> 
(2012, September 11).

LACINA, BETHANY, AND NILS PETTER GLEDITSCH. (2005) Monitoring Trends in Global Combat: A New Dataset of Battle Deaths. European Journal of Population 21(2-3):145-66.

LARI, ANDREA. (2007) Striving for Better Days: Improving the Lives of Internally Displaced People in Colombia. Washington, DC: Refugees International.

LARI, ANDREA, AND JAKE KURTZER. (2008) Colombia: Key Facts on Recent Displacement in Arauca. Refugees International $<\mathrm{http}$ ///refugeesinternational.org/content/colombia-key-facts-recent-displacementarauca $>$ (2014, August 8).

LATIN AMERICAN HERALD TRIBUNE. (2009) Guerrilla Attack Causes Blackout in Eastern Colombia. $<$ http://www.laht.com/article.asp?ArticleId=335300\&CategoryId=12393> (2014, August 22).

LEECH, GARY. (2011) The FARC: The Longest Insurgency. London: Zed Books.

LEECH, GARRY. (2006) Crude Interventions: The United States, Oil and the New World (Dis)Order. London: Zed Books.

LEECH, GARRY. (2003) The Battle for Colombia's "Little Sarajevo." North American Congress on Latin America 36(5):19-45.

LEECH, GARRY. (2002) Colombia Court Declares Rehabilitation Zones Unconstitutional. Colombia Journal. <http://colombiajournal.org/colombia-court-declaresrehabilitation-zones-unconstitutional.htm> (2012, September 10).

LEECH, GARY. (2000b) US Aid Package Amounts to Corporate Welfare. $<$ http://colombiajournal.org/colombia28.htm> (2012, August 9).

LEECH, GARY. (2000a) The Case of the U'wa. <http://web.archive.org/web/20070618074533/http://www.colombiajournal.org/colom bia17.htm> (2012, August 9).

LEÓN, JUANITA. (2003) La Reconquista de Arauca. Semana 
<http://www.semana.com/nacion/articulo/la-reconquista-arauca/56223-3> (2014, September 18).

LI, QUAN (2006) Political Violence and Foreign Direct Investment. In Regional Economic Integration, edited by Michele Fratianni, 225-249. Oxford, UK: JAI Press.

LIVINGSTONE, GRACE. (2003) Inside Colombia: Drugs, Democracy and War. New Brunswick, New Jersey: Rutgers University Press.

\section{LOZANO-GRACIA, NANCY, GIANFRANCO PIRAS, ANA M. IBÁÑEZ, AND}

GEOFFREY J. D. HEWINGS. (2010) The Journey to Safety: Conflict-Driven Migration Flows in Colombia. International Regional Science Review 33(2):157-80.

MAHER, DAVID. (2014) Rooted in Violence: Civil War, International Trade and the Expansion of Palm Oil in Colombia. New Political Economy <http://dx.doi.org/10.1080/13563467.2014.923825>

MAHER, DAVID, AND ANDREW THOMSON. (2011) The Terror that Underpins the "Peace": the Political Economy of Colombia's Paramilitary Demobilisation Process. Critical Studies on Terrorism 4(1):95-13.

MARSHALL, MONTY G., TED ROBERT GURR, AND KEITH JAGGERS. (2014) Polity ${ }^{\mathrm{TM}}$ IV Project: Political Regime Characteristics and Transitions, 1800-2013. <http://www.systemicpeace.org/inscrdata.html> (2014, August 8).

MARX, GARY. (2002) Imperiled pipeline gets U.S. troops in Colombia. Chicago Tribune $<$ http://articles.chicagotribune.com/2002-11-12/news/0211120147_1_colombiangovernment-leftist-rebels-president-alvaro-uribe> (2011, August 9).

MARX, KARL (1990) Capital: A Critique of Political Economy. Trans. Ben Fowkes. Vol. 1. London: Penguin.

MIHALACHE-O'KEEF, ANDREEA, AND TATIANA VASHCHILKO. (2010) Foreign direct investors in conflict zones. In: Mats Berdal and Achim Wennman (eds.) Ending Wars, Consolidating Peace: Economic Perspectives. London: Routledge/IISS (Adelphi Series 50: 412-413), 137-156.

MINISTERIO DE DEFENSA. (2014) Logros de la Política Integral de Seguridad y Defensa 
para la Prosperidad - PISDP. Bogotá: República de Colombia.

MELANDER, ERIK, AND RALPH SUNDBERG. (2011) Climate Change, Environmental Stress, and Violent Conflict - Test Introducing The UCDP Georeferenced Event Dataset. Paper presented to the Annual Convention of the International Studies Association, Montreal, Canada, March 16-19.

MICHAUD, YVETTE. (2007) ¡Viva Sintracarbón! Three Weeks with a Colombian Union. In The People Behind Colombian Coal: Mining, Multinationals and Human Rights, edited by Aviva Chomsky, Garry Leech, and Steve Striffler, 181-186.

MOLINSKI, DAN. (2012) Colombia Forces Kill 33 FARC Rebels in Arauca. Wall Street Journal. <http://online.wsj.com/article/SB10001424052702304724404577295590524111120.h tml> (2013, March 5).

MOSER, CAROLINE. (2000) "Violence in Colombia: Building Sustainable Peace and Social Capital." In Essays on Conflict, Peace, and Development. Conflict Prevention and Post-conflict Reconstruction, edited by Andres Solimano, pp. 9-77. Washington, DC: World Bank.

MUGGAH, H. C. R. (2000) Conflict-Induced Displacement and Involuntary Resettlement in Colombia. Disasters 24(3):198-216.

MURILLO, MARIO A. (2004) Colombia and the United States: War, Unrest and Destabilization. New York: Seven Stories Press.

MURDOCH, JAMES C., AND TODD SANDLER. (2004) Civil Wars and Economic Growth: Spatial Dispersion. American Journal of Political Science 48(1):138-51.

MURDOCH, JAMES C., AND TODD SANDLER. (2002a) Civil Wars and Economic Growth: A Regional Comparison. Defense and Peace Economics 13(6): 451-64.

MURDOCH, JAMES C. AND TODD SANDLER. (2002b) Economic Growth, Civil Wars, and Spatial Spillovers. Journal of Conflict Resolution 46(1): 91-110.

OFFICE OF THE UNITED NATIONS HIGH COMMISSIONER FOR HUMAN RIGHTS (OHCHR). (2003) Report of the United Nations High Commissioner for Human 
Rights on the Human Rights Situation in Colombia. Commission on Human Rights, Fifty-ninth session.

\section{OFFICE OF THE UNITED NATIONS HIGH COMMISSIONER FOR REFUGEES}

(UNHCR). (2008) Report Highlights Humanitarian Concerns in Colombia's Putumayo Region. <http://www.unhcr.org/cgibin/texis/vtx/refdaily?pass=463ef21123\&id=487c39b38> (2012, December 20).

O'GRADY, MARY ANASTASIA. February 6, 2004. Cooking the Human-Rights Books in Colombia. Wall Street Journal.

OHLSEN PETTERSSON, OLLE (2012) Neo-Paramilitaries Declare War against FARC, ELN in Northeastern Colombia. Colombia Reports. <http://colombiareports.co/neoparamilitaries-declare-war-against-rebels-in-northeastern-colombia/> (2013, September 16).

ORGANISATION FOR ECONOMIC CO-OPERATION AND DEVELOPMENT (OECD) (2012). OECD Investment Policy Reviews: Colombia 2012. n.p.: OECD Publishing. <http://dx.doi.org/10.1787/9789264167742-en> (2012, February 25).

PACIFIC RUBIALES (2011) Pacific Rubiales Provides Exploration Update For The Arauca E\&P Block. <http://www.pacificrubiales.com/2011/252-18072011-pacific-rubialesprovides-exploration-update-for-the-arauca-eap-block> (2014, March 25).

PACIFIC RUBIALES. (2007) Annual Report: 2007. Bogotá: Pacific Rubiales.

PALMER, LEO (2010) Army Complicit in Arauca Paramilitary Crimes. $<$ http://colombiareports.com/colombia-news/news/10935-army-complicit-in-araucaparamilitary-crimes-the-twin.html> (2012, August 11).

PERMANENT TRIBUNAL OF PEOPLES. (2007) Petroleum Industry Hearing. $<$ http://colombiasupport.net/2007/10/petroleum-industry-hearingpermanent-tribunalof-peoples/> (2014, August 8).

PETROTECH ENGINEERING. (2007) Evaluation of the Interests of Pacific Stratus Energy Ltd. in the Arauca Block in Llanos Basin in Colombia. N.p.: Petrotech Engineering.

PIPELINE AND GAS JOURNAL. (2010) Ecopetrol Seeks Partners For 1,545-Km 
Bicentennial Pipeline. Pipeline and Gas Journal 237(11).

$<\mathrm{http}: / /$ pipelineandgasjournal.com/ecopetrol-seeks-partners-1545-km-bicentennialpipeline> (2014, August 8).

PR NEWSWIRE (2011) Pacific Rubiales Provides Exploration Update for the Arauca E\&P Block. <http://www.sys-con.com/node/1911531> (2013, September 18).

PRESIDENCIA DE LA REPÚBLICA. (2003) Política de Defensa y Seguridad Democrática. Bogotá: Ministerio de Defensa Nacional, República de Colombia.

\section{RALEIGH, CLIONADH, ANDREW LINKE, HÅVARD HEGRE, AND JOAKIM} KARLSEN. (2010) Introducing ACLED: An Armed Conflict Location and Event Dataset. Journal of Peace Research 47(5):1-10.

REPSOL. (2009) Consolidated Management Report 2008. Madrid: Repsol.

REPSOL. (n.d.) Biodiversity Analysis and Determination of Environmental Conservation Objects in the Capachos field (Colombia) http://www.repsol.com/es_en/corporacion/responsabilidad-corporativa/como-lohacemos/casos-exito/buscador-casos-exito/analisis-biodiversidad-determinacionobjetos-conservacion-ambiental-campo-capachos-colombia.aspx> (2014, August 8).

REUTERS. (2011) Factbox, Colombia's Main Oil Regions: Risks and Output. <http://uk.reuters.com/article/2011/10/18/sm-colombia-oilidUKN1E7951XF20111018> (2012, December 20).

REUTERS. (2014) Colombia's Ecopetrol to Sell Half Stake in Capachos Block to Parex. $<$ http://www.reuters.com/article/2014/05/13/ecopetrol-parex-resourcesidUSL1N0NZ03S20140513> (2014, August 2014).

RIGHTS AND DEMOCRACY. (2001) Mission to Colombia to Investigate the Situation of Indigenous Peoples. N.p.: International Centre for Human Rights and Democratic Development.

RICHANI, NAZIH. (2002). Systems of Violence: The Political Economy of War and Peace in Colombia. Albany, NY: State University of New York Press.

SARKEES, MEREDITH R. (2000) The Correlates of War Data on War: An Update to 1997. 
Conflict Management and Peace Science 18(1):123-44.

SEMANA (2008) El Bloque Vencedores de Arauca. Informe de la FIP: Documento de la Fundación Ideas para la Paz. <http://www.semana.com/on-line/articulo/el-bloquevencedores-arauca/92458-3> (2013, February 26).

SEMANA. (2009) Guerrilla Attack Causes Blackout in Eastern Colombia $<$ http://www.semana.com/international/colombia-in-the-world/articulo/guerrillaattack-causes-blackout-in-eastern-colombia/103323-3> (2014, August 22).

SEMANA. (2011) DAS Captura a Julio Acosta, Exgobernador de Arauca. $<$ http://www.semana.com/nacion/das-captura-julio-acosta-exgobernadorarauca/153333-3.aspx> (2011, August 15).

SIERRA, ALVARO. March 9, 2003. Arauca: Entre la Guerra y la Estigmatización. El Tiempo.

SKAPERDAS, STERGIOS. (2009) “The Costs of Organized Violence: A Review of the Evidence.” In The Costs of Violence, edited by Stergios Skaperdas, Rodrigo Soares, Alys Willman, and Stephen C. Miller, pp. 1-25. Washington, DC: World Bank.

SMITH, CHRISTOPHER E. (2012) Near-Term Pipeline Plans Grow, Longer-Term Projects Sag. Oil \& Gas Journal. <http://www.ogj.com/articles/print/vol-110/issue2/transportation/special-report-worldwide/near-term-pipeline.html> (2014, March 25).

STEWART, FRANCES, AND VALPY FITZGERALD (2001) "Introduction: Assessing the Economic Costs of War." In War and Underdevelopment. Volume 1: The Economic and Social Consequences of Conflict, edited by Frances Stewart, Valpy FitzGerald, and Associates, pp. 1-20. Oxford: Oxford University Press.

STOKES, DOUG. (2005) America's Other War: Terrorizing Colombia. New York: Zed Books.

STOKES, DOUG, AND SAM RAPHAEL. (2010) Global Energy Security and American Hegemony. Baltimore, MD: Johns Hopkins University Press.

STRATFOR (2002) Oil Trumps Drug Eradication in U.S. Priorities for Colombia $<$ http://www.stratfor.com/>. 
SULIMAN, ADIL H., AND ANDRÉ VARELLA MOLLICK. (2009) Human Capital Development, War and Foreign Direct Investment in Sub-Saharan Africa. Oxford Development Studies 37(1):47-61.

SUMNER, ANDREW. (2005) Is Foreign Direct Investment Good for the Poor? A Review and Stocktake. Development in Practice 15(3/4):269-85.

TAYLOR, BRIAN D., AND ROXANA BOTEA. (2008) Tilly Tally: War-Making and StateMaking in the Contemporary Third World. International Studies Review 10(1):27-56.

TILLY, CHARLES. (1990) Coercion, Capital, and European States, AD 990-1990. Cambridge, Mass: Basil Blackwell.

THEMNÉR, LOTTA, AND PETER WALLENSTEEN. (2012) UCDP/PRIO armed conflict dataset. Journal of Peace Research 49(4):565-75.

THOMSON, FRANCES. (2011) The Agrarian Question and Violence in Colombia: Conflict and Development. Journal of Agrarian Change 11(3): 321-56.

UNIDAD DE PLANEACIÓN MINERO ENERGÉTICA (n.d.) Petroleo: Inversion en Colombia. $<$ http://www.upme.gov.co/generadorconsultas/Consulta_Series.aspx?idModulo=3\&ti poSerie $=44>(2013$, February 26$)$.

UNITED NATIONS CONFERENCE ON TRADE AND DEVELOPMENT (UNCTAD). (n.d.) Foreign Direct Investment. $<$ http://unctadstat.unctad.org/TableViewer/tableView.aspx>.

UNITED NATIONS OFFICE ON DRUGS AND CRIME (UNODC). (2009) Colombia: Coca Cultivation Survey. Vienna: UNODC.

US DEPARTMENT OF STATE (DOS). (2003b) Security in Arauca Major Political Task for Uribe. <http://www.state.gov/documents/organization/156471.pdf> (2012, September $11)$.

US DEPARTMENT OF STATE (DOS). (2003a) GOC Justice Program in Arauca a Model for other Conflictive Zones. <http://www.state.gov/documents/organization/156478.pdf> (2013, September 11). 
US DEPARTMENT OF STATE (DOS). (2002c) Oil and Natural Gas Exploration in Colombia. <http://www.state.gov/documents/organization/156620.pdf> (2012, September 11).

US DEPARTMENT OF STATE (DOS). (2002b) Staffdel Cardenas.

$<$ http://www.state.gov/documents/organization/156619.pdf> (2012, September 11).

US DEPARTMENT OF STATE (DOS). (2002a) Arauca Oil Production - Key Facts. <http://www.state.gov/documents/organization/156626.pdf> (2012, January 26).

US DEPARTMENT OF STATE (DOS). (2001a) Oil in Colombia: Potential Despite the Problems. <http://www.state.gov/documents/organization/156645.pdf> (2012, September 11).

US DEPARTMENT OF STATE (DOS). (2001b) Costly Losses: Repercussions of Petroleum Security Issues. <www.state.gov/documents/organization/156646.pdf> (2012, September 11).

US DEPARTMENT OF STATE (DOS). (2004) Colombia: Country Reports on Human Rights Practices. <http://www.state.gov/j/drl/rls/hrrpt/2003/27891.htm> (2014, August 8).

UNITED STATES DEPARTMENT OF STATE (DOS). (2006) Arauca and Catatumbo: 3 Keys to Security. Available from Wikileaks <https://wikileaks.org/plusd/cables/06BOGOTA10214_a.html> (2014, August 8).

UNITED STATES DEPARTMENT OF STATE (DOS). (2011) Colombia. <http://www.state.gov/e/eeb/rls/othr/ics/2011/157259.htm> (2012, November 1).

US ENERGY INFORMATION ADMINISTRATION. (2011) Colombia. $<$ http://205.254.135.7/countries/cab.cfm?fips=CO > (2012, September 11).

US GOVERNMENT ACCOUNTABILITY OFFICE (GOA). (2005) Security Assistance: Efforts to Secure Colombia's Caño Limón-Coveñas Oil Pipeline Have Reduced Attacks, but Challenges Remain. Washington, DC: General Accounting Office.

VERDAD ABIERTA. (2010) Desmovilizados Contaron Cómo Llegaron los Paras a Arauca $<$ http://www.verdadabierta.com/victimarios/2280> (2012, September 10).

VERDAD ABIERTA. (2009a) Yo Acuso: “Mellizo” Mejía. 
$<$ http://verdadabierta.com/justicia-y-paz/versiones-seccion/1908-yo-acuso-mellizomejia\#at> (2012, September 10).

VERDAD ABIERTA. (2009b) Alias “Cúcuta” Sindica a ex Gobernador de Arauca de Ordenar Asesinatos. <http://www.verdadabierta.com/justicia-y-paz/80-versiones/876aliascucuta-confirmo-presuntos-nexos-del-ex-gobernador-acosta-con-paras> (2012, September 12).

VERNEY MARIE-HÉLÈNE. (2007) Fresh Violence Forces Locals to Flee Eastern Colombia's Arauca Region. United Nations High Commissioner for Refugees $<$ http://www.unhcr.org/467fdfec2.html> (2014, August 8)

VERNEY MARIE-HÉLÈNE. (2008) Threats Force 2,000 Colombians to Flee From Countryside. United Nations High Commissioner for Refugees $<$ http://www.unhcr.org/cgibin/texis/vtx/search?page $=$ search \&docid $=4796290 \mathrm{e} 2 \&$ query $=$ Threats $\% 20$ force $\% 202$, 000\%20Colombians\%20to\%20flee\%20from\%20countryside> (2014, August 8)

WASHINGTON OFFICE ON LATIN AMERICA (WOLA). (2003) Colombia Monitor. Protecting the Pipeline: The US Military Mission Expands. Washington, DC: WOLA.

WILLIAMSON, JOHN. (1990) What Washington Means by Policy Reform. <http://www.iie.com/publications/papers/paper.cfm?ResearchID=486> (2010, October 8).

WITNESS FOR PEACE. (2002) The Real Costs of Pipeline Protection in Colombia: Corporate Welfare with Deadly Consequences. A Witness for Peace Report from Arauca. Washington, DC: Witness for Peace.

WORLD BANK (n.d.). Data. <http://data.worldbank.org/> (2013, March 11).

WORLD BANK. (2011) World Development Report 2011: Conflict, Security and Development. Washington, DC: The World Bank.

WORLD BANK. (2012) Income Share Held by Highest 10\% - Colombia. <http://data.worldbank.org/indicator/SI.DST.10TH.10> (2012, September 11). 